Prepared in cooperation with the U.S. Army Corps of Engineers, Omaha District

Characteristics of Suspended and Streambed Sediment within Constructed Chutes and the Main Channel at Upper Hamburg and Glovers Point Bends, Missouri River, Nebraska, 2008

Open-File Report 2011-1049 



\section{Characteristics of Suspended and Streambed Sediment within Constructed Chutes and the Main Channel at Upper Hamburg and Glovers Point Bends, Missouri River, Nebraska, 2008}

By Brenda K. Woodward and David L. Rus

Prepared in cooperation with the U.S. Army Corps of Engineers, Omaha District

Open-File Report 2011-1049 


\section{U.S. Department of the Interior \\ KEN SALAZAR, Secretary \\ U.S. Geological Survey \\ Marcia K. McNutt, Director}

\section{U.S. Geological Survey, Reston, Virginia: 2011}

For more information on the USGS - the Federal source for science about the Earth, its natural and living resources, natural hazards, and the environment, visit http://www.usgs.gov or call 1-888-ASK-USGS.

For an overview of USGS information products, including maps, imagery, and publications, visit http://www.usgs.gov/pubprod

Any use of trade, product, or firm names is for descriptive purposes only and does not imply endorsement by the U.S. Government.

Although this report is in the public domain, permission must be secured from the individual copyright owners to reproduce any copyrighted materials contained within this report.

Suggested citation:

Woodward, B.K., and Rus, D.L., 2011, Characteristics of suspended and streambed sediment within constructed chutes and the main channel at Upper Hamburg and Glovers Point Bends, Missouri River, Nebraska, 2008:

U.S. Geological Survey Open-File Report 2011-1049, 29 p. 


\section{Contents}

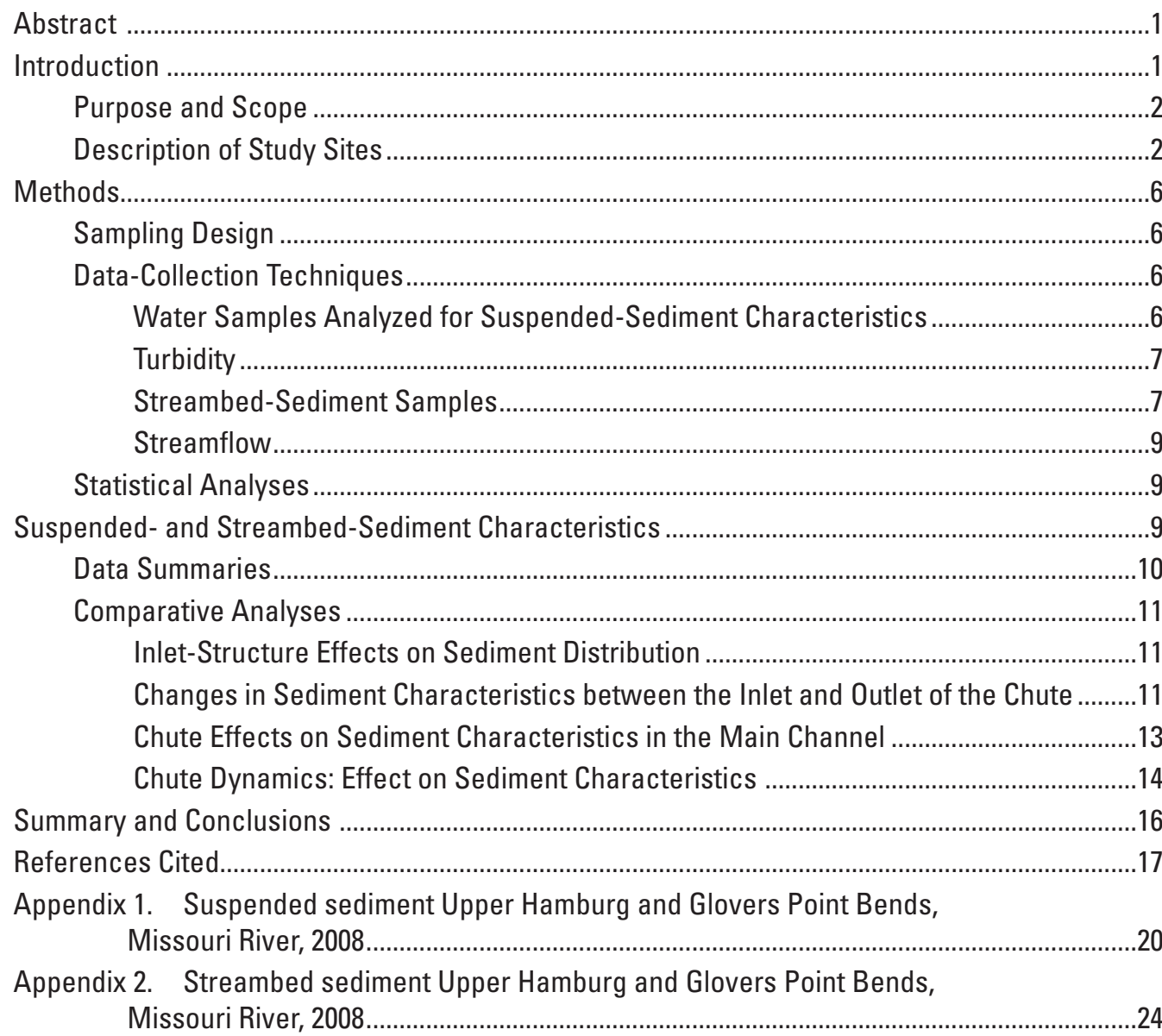

\section{Figures}

1. Map showing location of study sites sampled within the Missouri River for this study.

2. 2008 aerial orthophotography showing Upper Hamburg Bend sampling locations..........4

3. 2008 aerial orthophotography showing Glovers Point Bend sampling locations ..............5

4. Graph showing relative potential for chute-river system dynamics, as represented by Missouri River streamflow during the operational period of each chute studied

5. Graphs showing averaged streambed grain-size distributions for each site sampled, Missouri River, 2008

6. Graph showing relation of sample size to minimum detectable difference in suspended-sediment concentration for four groups of tested comparisons, Missouri River, 2008.

7. Photographs showing freshly eroded streambank and freshly deposited sediment in the Upper Hamburg Bend chute following a Missouri River flood event, June 2008 
8. Daily suspended-sediment concentration, Missouri River at Sioux City, lowa, and Missouri River at Nebraska City, Nebr., and discretely sampled concentrations measured for this study, May 2008 through September 2008

\section{Tables}

1. Transects and transect-sample types collected in 2008.................................................

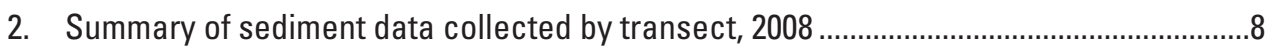

3. Summary of results from statistical comparisons made using paired t-tests, Missouri River, 2008.

4. Summary of results from statistical comparisons used to understand the effect of chute dynamics on sediment characteristics, Missouri River, 2008.

\section{Conversion Factors}

SI to Inch/Pound

\begin{tabular}{lll}
\hline Multiply & By & To obtain \\
\hline millimeter $(\mathrm{mm})$ & Length & \\
meter $(\mathrm{m})$ & 0.03937 & inch (in.) \\
kilometer $(\mathrm{km})$ & 3.281 & foot $(\mathrm{ft})$ \\
meter $(\mathrm{m})$ & 0.6214 & mile $(\mathrm{mi})$ \\
& 1.094 & yard $(\mathrm{yd})$ \\
\hline square kilometer $\left(\mathrm{km}^{2}\right)$ & Area & square mile $\left(\mathrm{mi}^{2}\right)$ \\
\hline & 0.3861 & \\
\hline meter per second $(\mathrm{m} / \mathrm{s})$ & Flow rate & feet per second $(\mathrm{ft} / \mathrm{s})$ \\
cubic meter per second $\left(\mathrm{m}^{3} / \mathrm{s}\right)$ & 3.281 & cubic foot per second $\left(\mathrm{ft}^{3} / \mathrm{s}\right)$ \\
\hline & 35.31 & gram $(\mathrm{g})$ \\
\hline ounce, avoirdupois $(\mathrm{oz})$ & Mass & kilogram $(\mathrm{kg})$ \\
\hline pound, avoirdupois $(\mathrm{lb})$ & 28.35 & \\
\hline & 0.4536 & liter $(\mathrm{L})$ \\
\hline ounce, fluid (fl. oz) & Volume & liter $(\mathrm{L})$ \\
\hline gallon (gal) & 0.02957 &
\end{tabular}

Temperature in degrees Celsius $\left({ }^{\circ} \mathrm{C}\right)$ may be converted to degrees Fahrenheit $\left({ }^{\circ} \mathrm{F}\right)$ as follows:

$$
{ }^{\circ} \mathrm{F}=\left(1.8 x^{\circ} \mathrm{C}\right)+32
$$

Vertical coordinate information is referenced to the North American Vertical Datum of 1988 (NAVD 88).

Horizontal coordinate information is referenced to the North American Datum of 1983 (NAD 83).

Concentrations of chemical constituents in water are given either in milligrams per liter (mg/L) or micrograms per liter $(\mu \mathrm{g} / \mathrm{L})$. 


\title{
Characteristics of Suspended and Streambed Sediment within Constructed Chutes and the Main Channel at Upper Hamburg and Glovers Point Bends, Missouri River, Nebraska, 2008
}

\author{
By Brenda K. Woodward and David L. Rus
}

\begin{abstract}
The U.S. Army Corps of Engineers, Omaha District, as part of the Missouri River Bank Stabilization and Navigation Mitigation Project, has constructed 17 off-channel chutes along the channelized Missouri River, downstream from Sioux City, Iowa, to increase habitat diversity. To better understand characteristics of suspended and streambed sediment within these constructed chutes, the U.S. Geological Survey investigated specific aspects of chute design and function in relation to sediment characteristics including: (1) effects of inlet structures; (2) changes occurring between the inlet and the outlet of a chute; (3) effects of chutes on sediment characteristics in the main channel; and (4) differences in chute dynamics between sampled chutes. Two chutes differing in design, location, and dynamics were studied, Upper Hamburg Bend near Nebraska City, Nebr., and Glovers Point Bend near Winnebago, Nebr. Each site was characterized using five or more sampling transects (two in the chute and three to four in the main channel) designed to bracket sediment exchanges between chutes and the main channel. A sixth transect was included at the Upper Hamburg Bend study site to account for the effects of a nontarget chute having its inlet midway between the inlet and outlet of the primary chute. Representative samples of suspended and streambed sediment were collected at each transect, along with measurements of turbidity and streamflow, between June and November 2008. Four sets of samples were collected at the Glovers Point Bend study site and five sample sets were collected from the Upper Hamburg Bend study site.

Results from paired $t$-tests and standard $t$-tests indicated that the inlet structure design, passing inflow only from the top of the main-channel water column, reduced the supply of coarse-grained suspended sediment entering the chutes. Statistical comparisons did not indicate differences between the inlet and outlet of either chute; however, anecdotal evidence of recent bank erosion and in-channel deposition was observed in both chutes during the study period. Chutes had little effect on Missouri River main-channel sediment characteristics,
\end{abstract}

which could be explained by the much greater streamflow of the main channel. Between-chute comparisons showed no significant differences in the suspended-sediment characteristics; however, the Upper Hamburg Bend chute had a coarser streambed, wider channel, and much greater streamflow than did the Glovers Point Bend chute.

\section{Introduction}

The U.S. Army Corps of Engineers (USACE), Omaha District, as part of the Missouri River Bank Stabilization and Navigation Mitigation Project (BSNP), has constructed 17 offchannel chutes along the channelized Missouri River, downstream from Sioux City, Iowa. These chutes were constructed to increase shallow-water habitat (defined by water less than 1.5 meters $(\mathrm{m})$ deep flowing with current velocity less than 0.75 meters per second $(\mathrm{m} / \mathrm{s})$ and determined at a streamflow equal to the August 50-percent flow exceedance) to mitigate the habitat lost through the creation and maintenance of the navigation channel on the main stem of the Missouri River (U.S. Fish and Wildlife Service, 2000). Channel evolution is allowed to occur, which creates natural, shallow-water habitats within the chutes. Habitat that has been created must be maintained and evaluated to understand how it is being used by aquatic species and what geomorphic processes are working within these chutes. This type of information is important from a scientific perspective and for river management decisions.

The primary goal of each chute project is to provide shallow-water habitat. Some chutes are fully constructed, whereas, other chutes are created by dredging a small pilot channel and allowing it to erode into a mature chute. Project design varies depending on the characteristics of land available and the chute location within the bend. Typically, chute inlets are designed to only allow the top portion of the Missouri River water column to enter the chute and to divert a maximum of 8-10 percent of the Missouri River streamflow. In general, current side-channel chutes, both self-maintaining 
and engineered, provide additional shallow-water, lowvelocity habitat adjacent to Missouri River bends. The habitat conditions found within the chutes typically can be found within the main channel only in limited areas (Jacobson and others, 2004).

Inlet-structure design is an important part of the construction of each chute. Inlet structures provide grade control for the chute and water control of the part of the Missouri River water column that enters the chute. Streambed elevation within the chute, as well as inlet angles, control water flow into the chute (Shields and Abt, 1989). The part of the water column diverting into the chute has a large effect on sediment transport within the chute explained by the theoretical distribution of sediment in the water column (Van Rijn, 1984). If the inlet structure is designed to only allow the top part of the water column into the chute, mainly fine sediment will be allowed into the chute (Horowitz, 2008). Therefore, the large grain-size fraction of the sediment load, which would otherwise fall out of suspension as velocity decreases within the chute and would be deposited at the mouth of the chute, is not allowed to enter. If the sediment transport capacity of a chute is not in equilibrium with the sediment supply at the inlet, the chute may eventually fill with sediment, alter the sediment regime of the main channel (Schropp, 1995; Barneveld and others, 1994), or capture the main channel (Slingerland and Smith, 1998).

A number of uncertainties are associated with chuteinlet design. The effect of control structures on the sediment budget within chutes of this type on the lower Missouri River has not been well documented, including how these structures affect physical habitat and erosion within the chute. Evaluation of sediment characteristics within the chutes will lead to an understanding of how current designs are performing. The effect of uncontrolled erosion within the chutes on the sediment characteristics of the Missouri River main channel also remains unclear. Finally, information is needed to document rates of chute evolution or erosion and how these affect the life cycle of each project. To address these uncertainties, the U.S. Geological Survey (USGS), in cooperation with the USACE, Omaha District, studied the characteristics of sediment at two bends of the Missouri River where chutes have been constructed-Upper Hamburg Bend and Glovers Point Bend.

\section{Purpose and Scope}

The purpose of this report is to describe the methods used to collect sediment samples and the suspended- and streambed-sediment characteristics of two constructed chutes of the Missouri River in 2008. The report presents comparisons made to investigate specific aspects of chute design and function in relation to sediment distribution including: (1) the effect of the inlet structure; (2) changes occurring between the inlet and the outlet of the chute; (3) the effect of the chutes on sediment characteristics in the main channel; and (4) the difference in chute dynamics between the two chutes sampled and the effect of sediment characteristics.

\section{Description of Study Sites}

Two chutes of differing design and dynamics were selected for the study (fig. 1). The first, Upper Hamburg Bend (UHAM) chute, is located along the right bank of the main channel, 891 kilometers $(\mathrm{km})$ above the mouth of the Missouri River (or river mile 554), downstream from Nebraska City, Nebr. The chute has a riprap control structure at its inlet that diverts water from the right bank of the Missouri River main channel into the chute (fig. 2). Water that enters the UHAM chute flows for approximately $5.0 \mathrm{~km}$ before returning to the Missouri River main channel. The UHAM chute was built in 1996 as a 3-m wide pilot channel, but has widened considerably since then with bankfull width approaching $80 \mathrm{~m}$ as of 2008. UHAM chute was studied previously by Jacobson and others (2004), who reported the chute had increased shallowwater habitat in the bend. Jacobson and others (2004) also documented lateral migration of the chute during 1998-2001. A complicating factor in the study of sediment distribution through the UHAM chute-river system is the presence of a second chute, constructed in 2004, along the left bank of the main channel (fig. 2).

The second study site, Glovers Point Bend (GLOVR) chute, is located along the right bank of the Missouri River, approximately 1,147 km above the mouth (river mile 713), and near Winnebago, Nebr. (fig. 1). The chute was constructed in 2007 as a $30.5-\mathrm{m}$ wide channel. A reverse-sill structure located in the main channel just upstream from the GLOVR inlet directs water flow toward the chute. The inlet is designed to allow water to flow into the chute from the top section of the Missouri River water column. The GLOVR chute flows for approximately $3.2 \mathrm{~km}$ before reconnecting with the main channel. The chute includes a road crossing over a culvert that currently serves as a grade-control structure located $0.6 \mathrm{~km}$ downstream from the chute inlet (fig. 3). Just upstream from the chute outlet is an inlet to a large area of backwater habitat to the left of the chute.

In addition to the design differences between the two chute projects, streamflow differences have a substantial effect on chute dynamics. From a geomorphic perspective, the streamflow regime imposed upon each chute is an important factor affecting the channel evolution, because the hydraulic power of streamflow provides the sediment-transport mechanism by which the chutes erode or aggrade toward their chute-specific equilibrium state. Although streamflow within the two chutes is not gaged, the UHAM chute-river system has had greater annual and peak streamflows, and thus a greater possibility of geomorphic work (energy dissipated) than has the GLOVR chute-river system, both during the years of their respective existence and in terms of cumulative streamflow (fig. 4). 


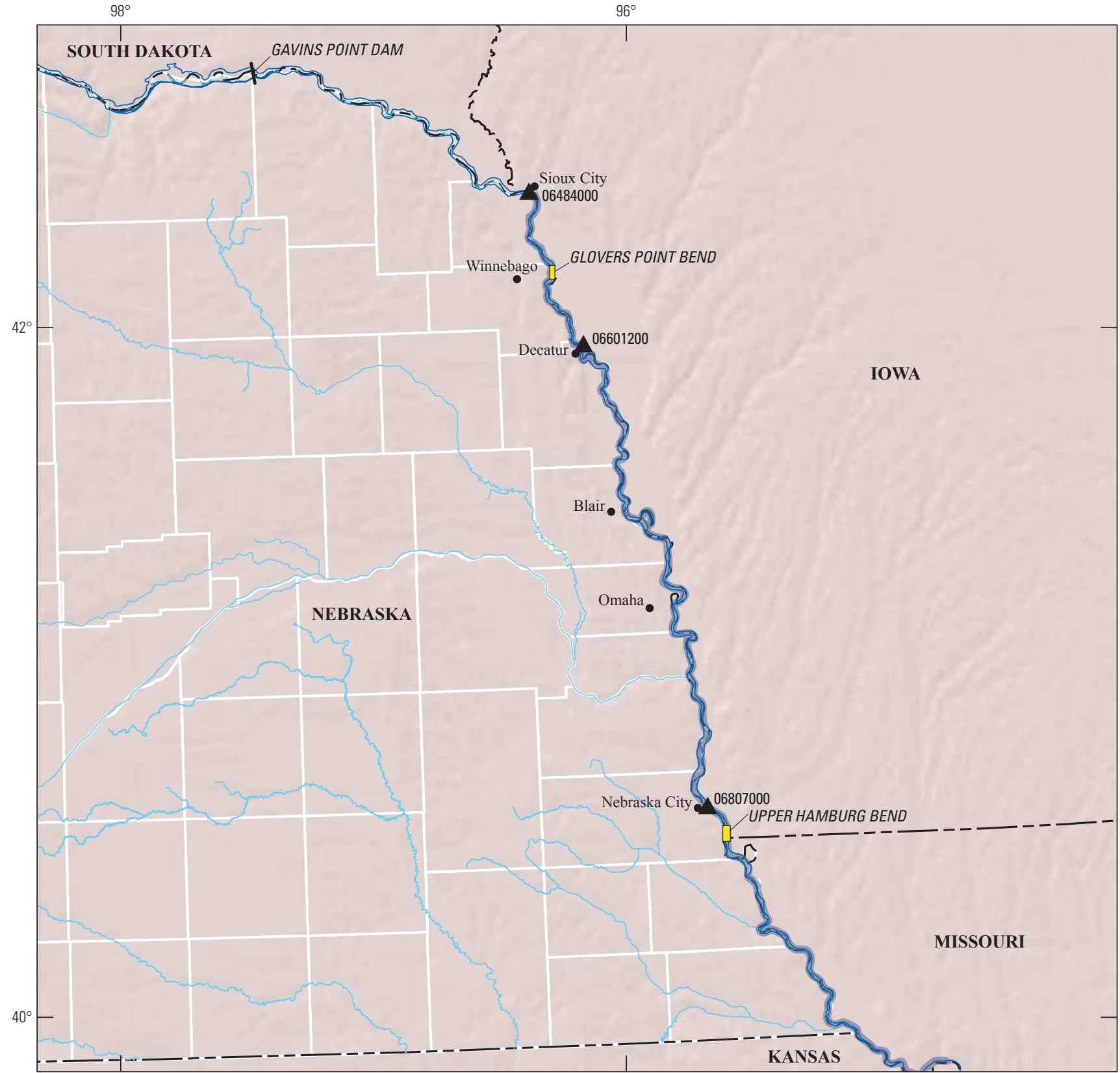

Base from Nebraska Department of Natural Resources digital data, 2005, 1:24,000

Nebraska State Plane FIPS zone 2600

Standard parallels $40^{\circ} \mathrm{N}$ and $43^{\circ} \mathrm{N}$

North American Datum of 1983 (NAD 83)
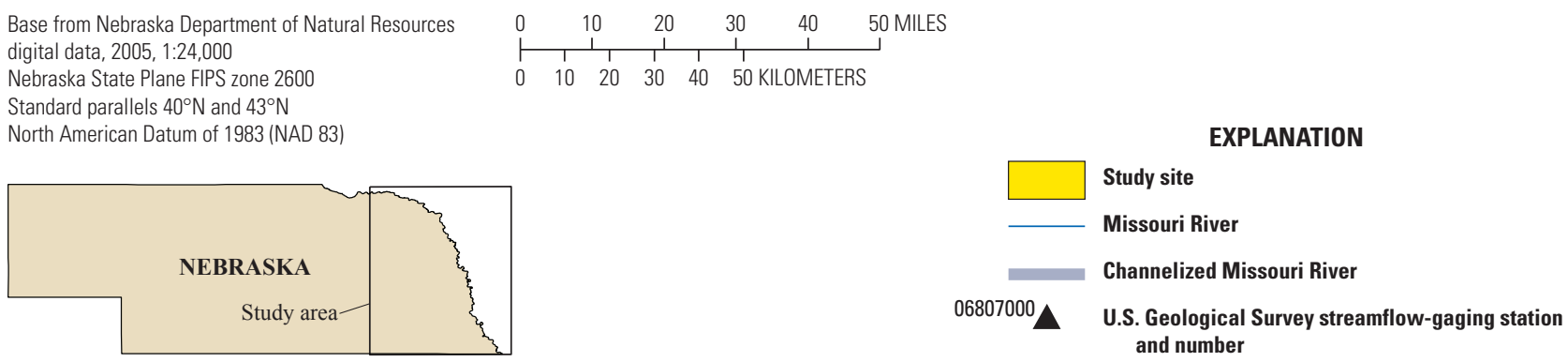

Figure 1. Location of study sites sampled within the Missouri River for this study. 


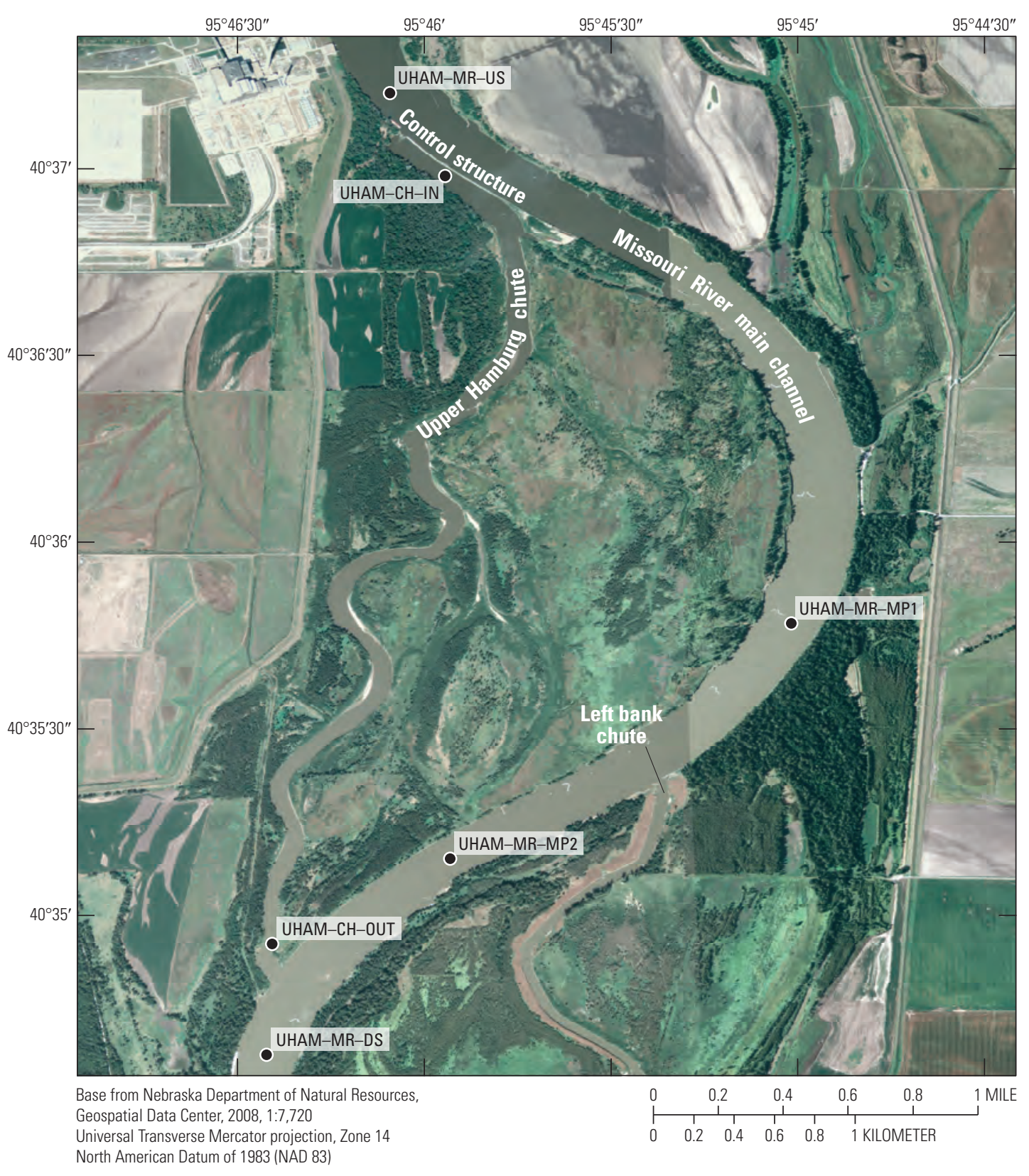

Chute inlet closeup

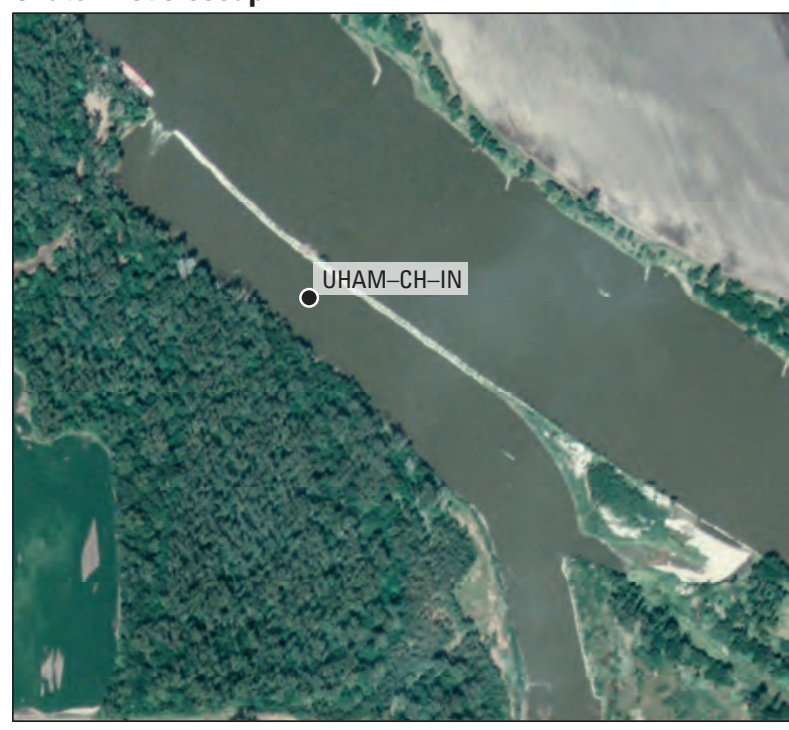

Chute outlet closeup

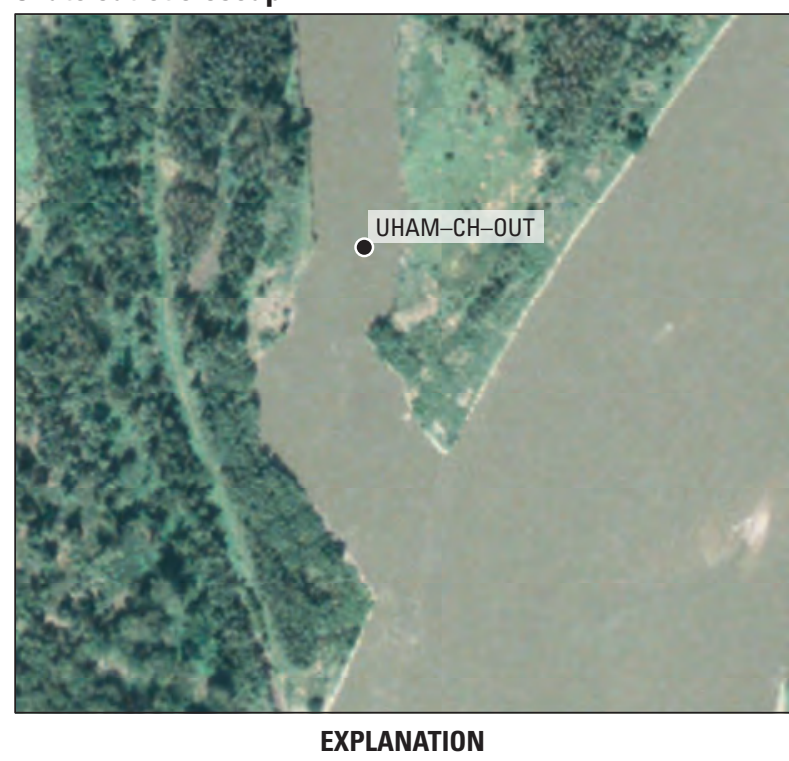

- Sediment sampling transect

Abbreviations: UHAM, Upper Hamburg Bend; MR, Missouri River; $\mathrm{CH}$, chute; IN, inlet; OUT, outlet; US, upstream; MP, midpoint; DS, downstream

Figure 2. 2008 aerial orthophotography showing Upper Hamburg Bend sampling locations. 


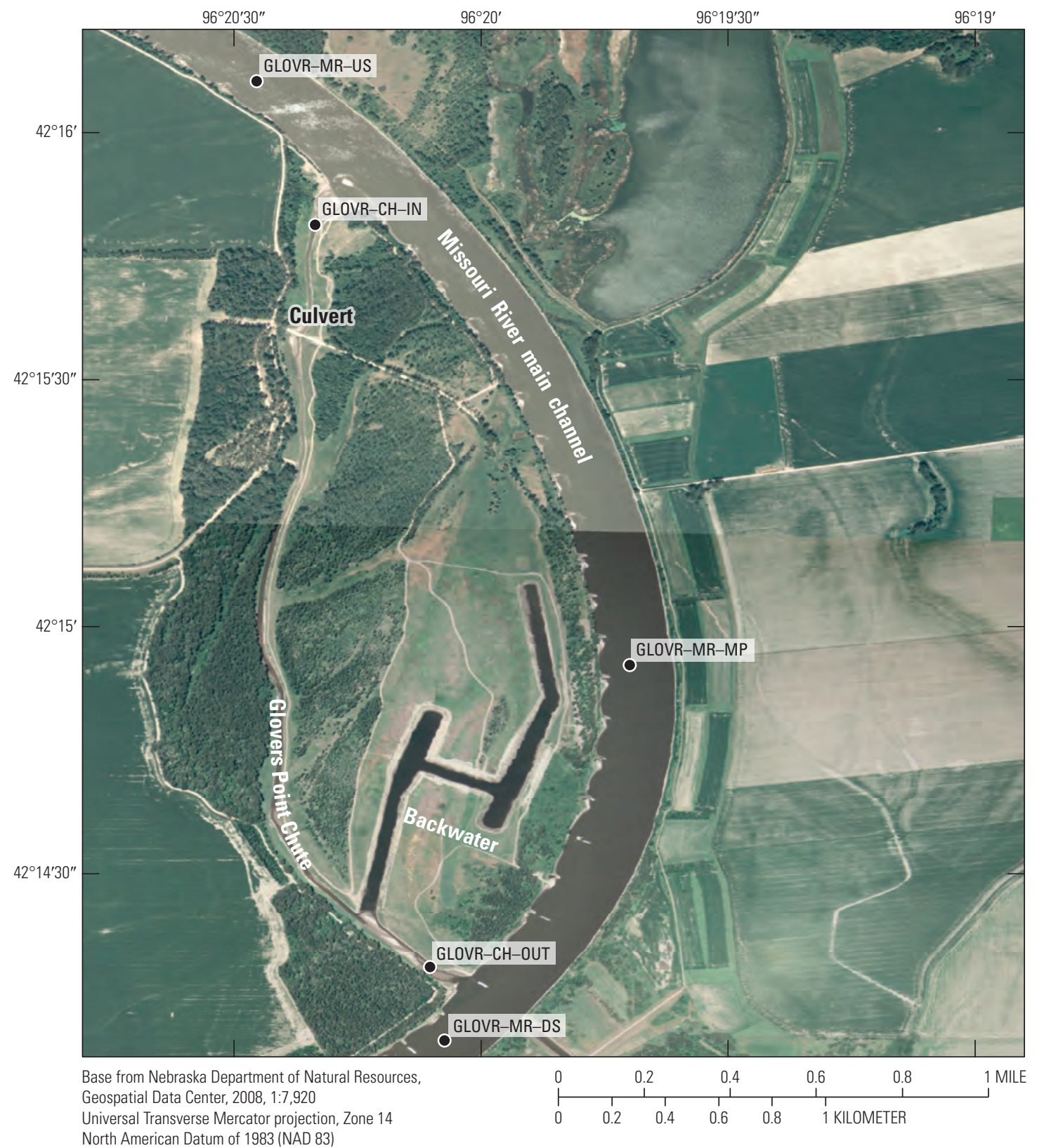

North American Datum of 1983 (NAD 83)

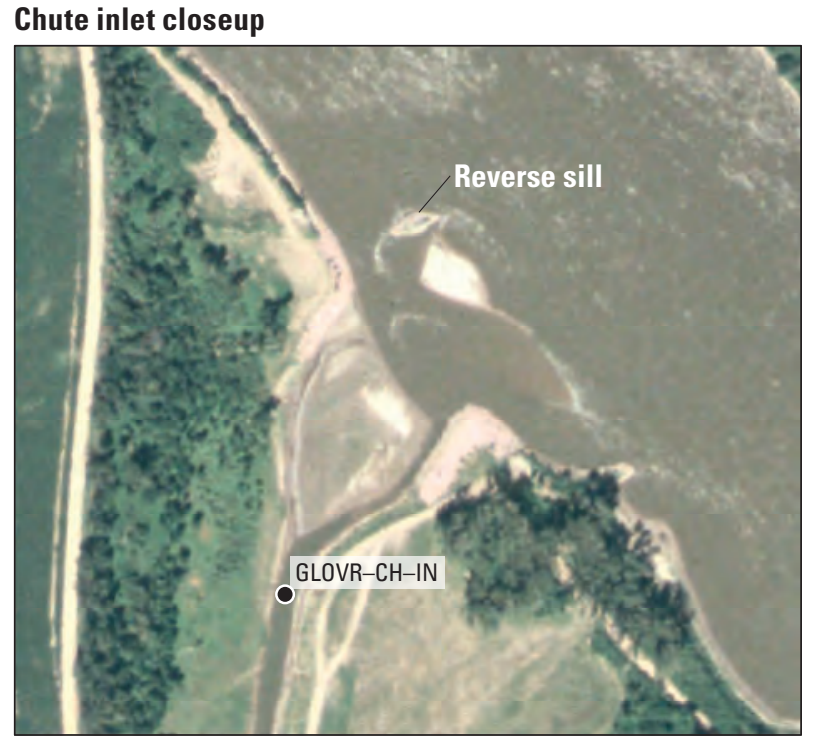

Backwater inlet closeup

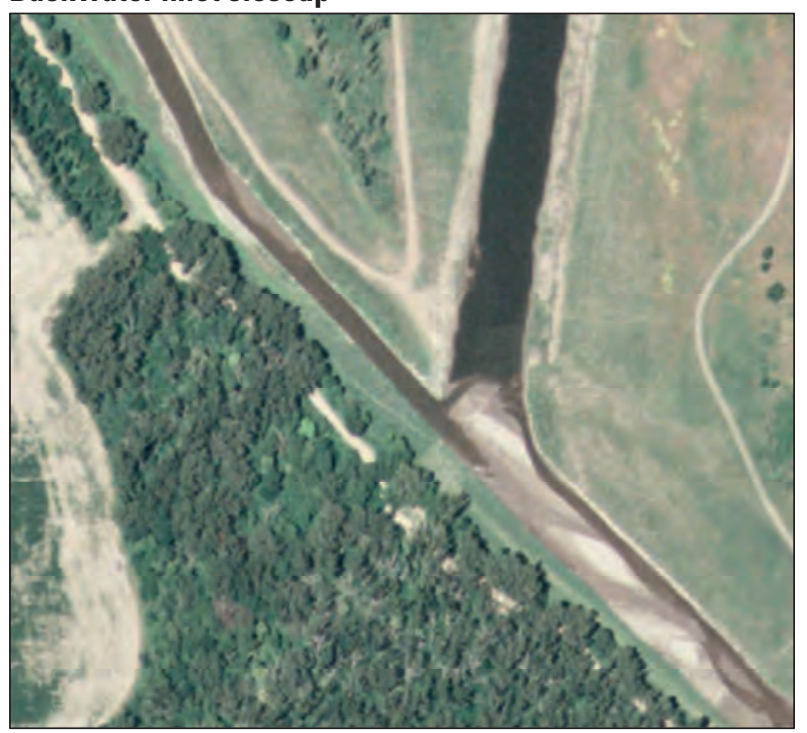

EXPLANATION

- Sediment sampling transect

Abbreviations: GLOVR, Glovers Point Bend; MR, Missouri River; $\mathrm{CH}$, chute; IN, inlet; OUT, outlet; US, upstream; MP, midpoint; DS, downstream

Figure 3. 2008 aerial orthophotography showing Glovers Point Bend sampling locations. 


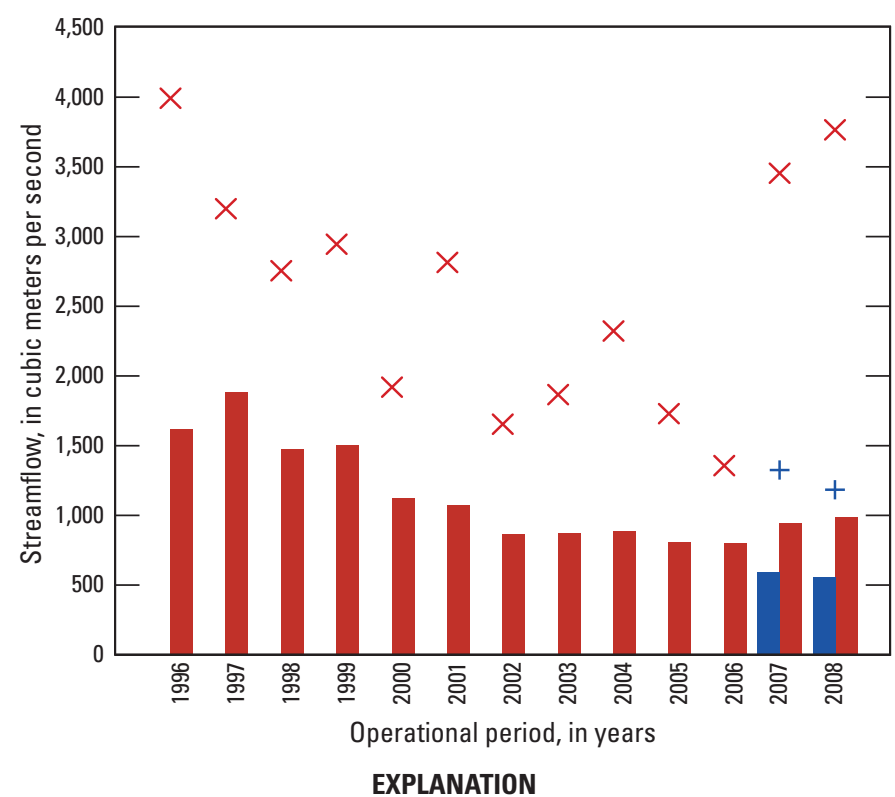

Mean annual flow, 0ct. 1-Sept. 30, Missouri River near Decatur, Nebr.

Mean annual flow, 0ct. 1-Sept. 30, Missouri River near Nebraska City, Nebr.

$+\quad$ Peak flow, Oct. 1-Sept. 30, Missouri River near Decatur, Nebr.

X Peak flow, 0ct. 1-Sept. 30, Missouri River near Nebraska City, Nebr.

U.S. Geological Survey National Water Information System: http://waterdata.usgs.giv/nwis/sw)

Figure 4. Relative potential for chute-river system dynamics, as represented by Missouri River streamflow (measured at nearby U.S. Geological Survey streamflow-gaging stations) during the operational period of each chute studied.

\section{Methods}

The general approach of this study was to collect a suspended- and streambed-sediment data set that allowed for multiple paired comparisons between different locations within a site and between sites. Each site was characterized by a series of transects set up to bracket the effects of the chute on suspended sediment, and each set of transects was sampled on multiple occasions. At each transect suspended-sediment and streambed-sediment data were collected. Statistical comparisons focused on four main sediment-transport effects of chute design and function, as described in the purpose and scope section (inlet-structure effects, within-chute changes, chute effects on the main channel sediment characteristics, and differences in chute dynamics).

\section{Sampling Design}

To allow the desired comparisons, each site was characterized using a series of sampling transects. Each transect was located to represent the sediment-transport conditions upstream or downstream from a location of potential exchanges within the chute-river system. The following specific exchanges were targeted: (1) diversion of main-channel water into the chute, (2) the channel-forming processes of erosion and deposition within the chute, and (3) the return of chute water back to the main channel. At each site, a minimum of five transects was required to bracket these exchange locations (table 1, figs. 2 and 3). Three transects were located on the main channel and were upstream from, at approximately the midpoint, and downstream from the chute. Two more transects were located within the chute-one near the inlet (downstream from the control structure) and one near the outlet. These chute transects bracketed the sediment exchanges associated with chute dynamics (the energy-dissipation history and potential of each site where energy dissipation is a function of cumulative flow, chute design, chute location, hydrologic regime, source sediment supplies, and chute bank materials) at each site.

At the UHAM site, a left-bank chute had its inlet from the main channel located between the inlet and outlet of the right-bank chute being studied (fig. 2). In order to evaluate the sediment-transport effect of the right-bank chute, the effect of the left-bank chute had to be removed from the main-channel transport conditions. To do so, a sixth transect was added to the main channel as a second midpoint transect at the UHAM site to isolate the left-bank chute's effect on transport in the main channel.

During 2008, the UHAM transects were sampled on five separate occasions, and the GLOVR transects were sampled on four occasions. These sample events represented a range of Missouri River streamflows from 561 to $1,140 \mathrm{~m}^{3} / \mathrm{s}$ (table 2). Sampled flows within the chutes ranged from about 0.8 to $172 \mathrm{~m}^{3} / \mathrm{s}$. The first sets of samples were collected in June 2008, and the final sets were collected in September and November 2008 at the GLOVR and UHAM sites, respectively.

\section{Data-Collection Techniques}

Sediment at each transect was characterized through the collection of representative samples of suspended and streambed sediment, the measurement of streamflow, and the determination of turbidity. All samples were collected following USGS protocols and are described in the following section.

\section{Water Samples Analyzed for Suspended- Sediment Characteristics}

All water samples were collected following the accepted protocols of the USGS (U.S. Geological Survey, variously dated). For wadeable transects (limited to the GLOVR chute during normal or low streamflows), a US DH-48 sampler (Davis, 2005) attached to a wading rod was transited vertically through the water column to fill the sample bottle. For nonwadeable transects, a US D-96 or a US DH-2 (Davis, 2005) was transited through the water column using a crane 
Table 1. Transects and transect-sample types collected in 2008.

[ID, identifier; UHAM, Upper Hamburg Bend; GLOVR, Glovers Point Bend; MR, Missouri River; US, upstream; MP, midpoint; DS, downstream; IN, inlet; OUT, outlet; R, River; NE, Nebraska; SS, suspended sediment; SB, streambed sediment; X, samples of the indicated type were collected at the indicated transect; --, samples of the indicated type were not colleccted at the indicated transect]

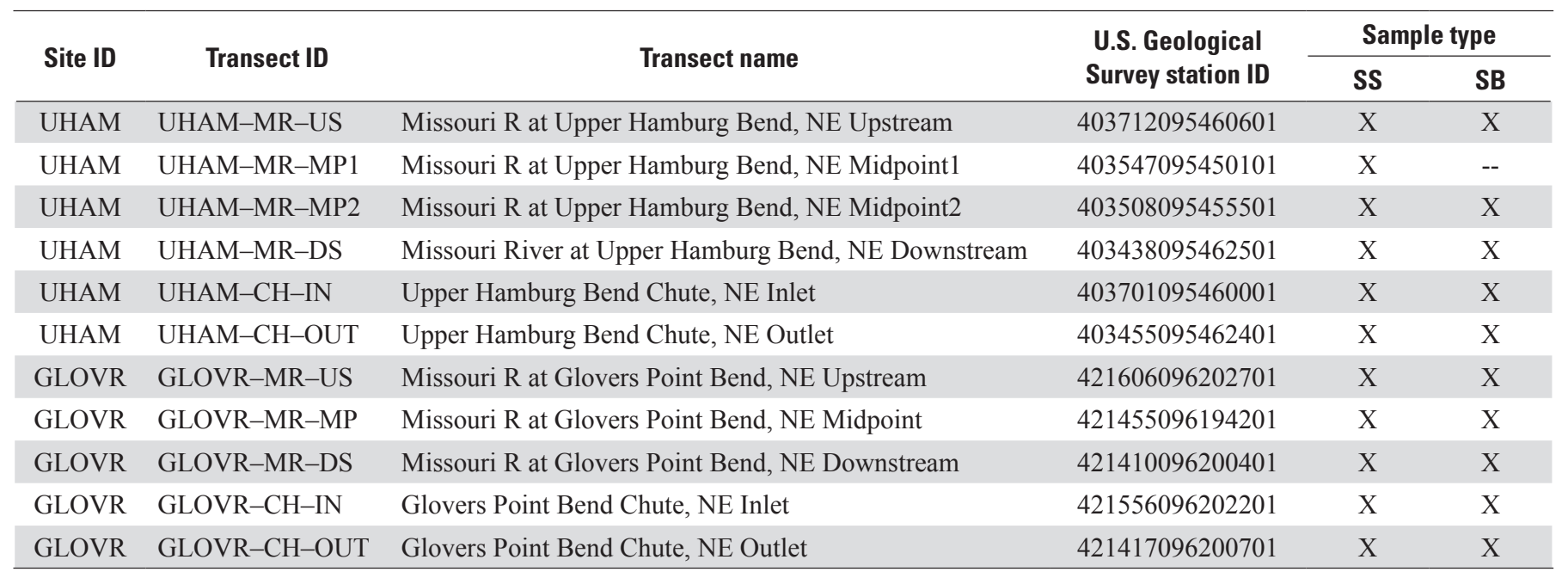

system mounted on the bow of a boat. In all cases, a constant, isokinetic transit rate (Edwards and Glysson, 1999) was used to collect the water sample at each sampled vertical across a transect. The water sample was collected at the center vertical from each of 10 equal-width increments of a transect and composited into a polyethylene churn-splitter container. Subsequently, an aliquot was split from the composite sample and submitted for laboratory analysis.

Samples were analyzed by the USGS Iowa Sediment Laboratory at Iowa City, Iowa, for total suspended-sediment concentration and the fraction of sediment mass finer than sand (SF) (operationally defined here as particles finer than 0.062 millimeter $(\mathrm{mm})$ in diameter). A subset of samples also was analyzed for grain-size distribution using a visualaccumulation-tube technique (Guy, 1969). This technique characterized samples by determining the corresponding fractions of suspended sediment finer than $0.0625,0.125,0.25$, and $0.5 \mathrm{~mm}$ in diameter.

\section{Turbidity}

Turbidity was measured in conjunction with the suspended-sediment sampling described previously. An aliquot of the composite sample was split from the churn for turbidity analysis. Five turbidity readings were taken of the aliquot and the median value was reported. Turbidity measurements were made using a Hach model 2100P turbidimeter (Hach Company, Loveland, Colo.).

\section{Streambed-Sediment Samples}

Streambed-sediment samples were collected at all but one transect. At the UHAM site, the streambed sediment in the main channel and in the right-bank chute was assumed to be unaffected by the inlet of the left-bank chute, and thus no samples were collected from the transect immediately upstream from that inlet (transect UHAM-MR-MP1, table 1). Samples were collected using a US BM-54 in nonwadeable transects and a US BMH-53 on wadeable transects (Davis, 2005). Streambed subsamples were collected from five points along a transect that corresponded to alternate points where suspended sediment was sampled. Occasionally, subsamples could not be successfully collected from one or more of the five points. This circumstance was most common along the margins of the main channel and was presumably the result of streambed materials (such as artificial riprap) being larger than the sampling orifice. The subsamples that were successfully collected were composited before being analyzed.

Samples were analyzed by the USGS Iowa Sediment Laboratory using standard sieve analyses that determined the fraction of streambed sediments finer than $0.0625,0.075$, $0.150,0.212,0.3,0.425,0.6,1.18,2.36,4.75,9.50$, and $19.0 \mathrm{~mm}$ in diameter. Using linear interpolation between the determined percentages, the diameters corresponding to the 16th $\left(\mathrm{d}_{16}\right)$, 50th $\left(\mathrm{d}_{50}\right.$, or median), and 84 th $\left(\mathrm{d}_{84}\right)$ percentiles of the grain-size distribution were estimated for each sample. Furthermore, the heterogeneity of each sample was numerically quantified as the difference between $\mathrm{d}_{84}$ and $\mathrm{d}_{16}$, or $\mathrm{d}_{84-16}$. 
Table 2. Summary of sediment data collected by transect, 2008.

[ID, identifier; $\mathrm{Q}_{\max }$, maximum streamflow associated with a set of samples; $\mathrm{Q}_{\min }$, minimum streamflow associated with a set of samples; $\mathrm{m}^{3} / \mathrm{s}$, cubic meters per second; $\mathrm{SSC}_{\mathrm{t}}$, total suspended-sediment concentration; $\mathrm{mg} / \mathrm{L}$, milligrams per liter; $\mathrm{SF}$, fraction of sample finer than 0.0625 millimeters; \%, percent; NTRU, nephelometric turbidity ratio units; $\mathrm{d}_{50}$, median diameter; mm, millimeters; $\mathrm{d}_{84.16}$, difference in diameter between the 84th and 16th percentiles of the grain-size distribution; --, not applicable]

\begin{tabular}{|c|c|c|c|c|c|c|c|c|c|c|c|}
\hline \multirow[b]{2}{*}{ Site ID } & \multirow[b]{2}{*}{ Transect ID } & \multirow[b]{2}{*}{$\begin{array}{l}{ }^{2} Q_{\text {max }^{\prime}} \\
\text { in } \mathrm{m}^{3} / \mathrm{s}\end{array}$} & \multirow[b]{2}{*}{$\begin{array}{l}{ }^{2} \mathbf{Q}_{\min } \\
\text { in } \mathrm{m}^{3} / \mathrm{s}\end{array}$} & \multicolumn{4}{|c|}{ Suspended-sediment samples } & \multicolumn{4}{|c|}{ Streambed-sediment samples } \\
\hline & & & & $\begin{array}{l}\text { Number of } \\
\text { samples }\end{array}$ & $\begin{array}{l}\text { Average SSC, } \\
\text { in } \mathrm{mg} / \mathrm{L}\end{array}$ & $\begin{array}{l}\text { Average SF, } \\
\text { in } \%\end{array}$ & $\begin{array}{l}\text { Average } \\
\text { turbidity, } \\
\text { in NTRU }\end{array}$ & $\begin{array}{l}\text { Number of } \\
\text { samples }\end{array}$ & $\begin{array}{l}\text { Average } \mathrm{d}_{50^{\prime}} \\
\text { in } \mathrm{mm}\end{array}$ & $\begin{array}{c}\text { Average } \\
d_{84-16^{\prime}} \\
\text { in mm }\end{array}$ & $\begin{array}{c}\text { Average SF, } \\
\text { in } \%\end{array}$ \\
\hline UHAM & UHAM-MR-US & 1,140 & 648 & 14 & 416 & 47 & 134 & 5 & 0.46 & 1.81 & 6.8 \\
\hline UHAM & UHAM-MR-MP1 & 977 & 643 & 13 & 474 & 46 & 160 & -- & -- & -- & -- \\
\hline UHAM & UHAM-MR-MP2 & 977 & 643 & 5 & 536 & 47 & 137 & 5 & .38 & .84 & .0 \\
\hline UHAM & UHAM-MR-DS & 1,140 & 648 & 5 & 507 & 52 & 139 & 5 & .34 & .77 & 1.2 \\
\hline UHAM & UHAM-CH-IN & 172 & 6.65 & 5 & 304 & 91 & 141 & 5 & .63 & 3.13 & 7.0 \\
\hline UHAM & UHAM-CH-OUT & 172 & 6.65 & 5 & 354 & 86 & 145 & 5 & .44 & 1.13 & 5.8 \\
\hline GLOVR & GLOVR-MR-US & 796 & 561 & 4 & 405 & 61 & 250 & 4 & .35 & .40 & 5.0 \\
\hline GLOVR & GLOVR-MR-MP & 790 & 561 & 4 & 378 & 67 & 240 & 4 & .37 & .38 & 2.3 \\
\hline GLOVR & GLOVR-MR-DS & 796 & 561 & 4 & 480 & 59 & 236 & 4 & .42 & .69 & 2.3 \\
\hline GLOVR & GLOVR-CH-IN & 10.4 & .79 & 4 & 274 & 89 & 216 & 4 & .17 & .16 & 11.5 \\
\hline GLOVR & GLOVR-CH-OUT & 10.4 & .79 & 4 & 365 & 72 & 251 & 4 & .24 & .26 & 6.8 \\
\hline
\end{tabular}

${ }^{1}$ One of the associated samples was inadvertantly destroyed during shipment to the laboratory.

${ }^{2}$ Streamflow data from U.S. Geological Survey National Water Information System: http://waterdata.usgs.gov/nwis/sw. 


\section{Streamflow}

Streamflow measurements were made following USGS standard protocol (Oberg and others, 2005; Mueller and Wagner, 2008). During each sampling event, streamflow was measured at one main-channel transect and one chute transect. Streamflow for all other transects at that site was estimated from those two measurements. Streamflow entering the leftbank chute at the UHAM site was not measured, and for the stated purpose of determining the sediment-transport effects of the right-bank chute, was assumed to have a negligible effect on streamflow in the main channel.

At nonwadeable transects, streamflow was measured using an acoustic Doppler current profiler in conjunction with a differential global positioning system receiver and a 200 kilohertz $(\mathrm{kHz})$ single-beam depth sounder. At wadeable transects, streamflow was measured using either an acoustic Doppler velocimeter or an acoustic Doppler current profiler mounted on a tethered boat.

\section{Statistical Analyses}

Statistical comparison tests and corresponding significance levels derived from Student's $t$ distribution were used to evaluate the effects of each chute on sediment characteristics. Because there were only nine sampling events, the Student's $t$ statistic was used for these tests. The distribution of the $t$ statistic is similar to a normal distribution but presumes more variance as a function of the sample size, thus making it preferable for small sample sizes such as were available in this study (Ott and Longnecker, 2001). Paired $t$-tests and standard $t$-tests with unequal variance were used to determine whether two subsets of samples were different from one another. Paired $t$-tests were preferred because they can detect smaller differences by removing extraneous variability (such as might be caused by varying streamflow conditions) from the comparisons. For paired $t$-tests, samples were paired by the day of sample collection, thus allowing for intrasite comparisons. For intersite and streamflow-gaging station comparisons, standard $t$-tests (adjusted for the effects of unequal variability between the two data sets) were used. Data subsets were declared to be significantly different at the 95-percent confidence level $(a l p h a=0.05)$. For each test result reported, the corresponding $p$-value also is reported. The $p$-value represents the probability that the statistical test results, or more extreme values, could have occurred if the null hypothesis was true. In the comparisons, the null hypothesis is that the two samples are not different. A $p$-value smaller than the alpha level (or rejection level) of 0.05 indicates that the statistical test outcome provides evidence that the null hypothesis is false, because the results are rare in an instant where the null hypothesis is true. Therefore, if the resulting $p$-value is less than 0.05 , the test statistic is shown to be significant, meaning that the null hypothesis (the two samples being the same) is rejected and the two samples are declared with 95-percent confidence to be significantly different.
Data were grouped into a series of subsets corresponding to testing each of four effects of the chutes on sediment characteristics. The main-channel transects upstream from the chute $(<$ SITE IDENTIFIER (ID) $>$-MR-US, table 1) were paired to chute transects at the inlet $(<$ SITE ID $>-\mathrm{CH}-\mathrm{IN})$ to determine the effects of the inlet structure. The chute transects at the inlet were paired to the chute transects at the outlet $(<$ SITE ID $>$-CH-OUT) to identify any change in sediment characteristic within the chutes. For identifying the effects of the chute on main-channel sediment characteristics, two sets of groupings were used: (1) main-channel transects upstream from the chute were paired with main-channel transects downstream from the chute $(<$ SITE ID $>$-MR-DS) to determine if the chutes had an overall effect on sediment characteristics in the main channel and (2) main-channel transects at the mid-point of the chute ( $<$ SITE ID $>$-MR-MP; MP2 at UHAM) were paired with main-channel transects downstream from the chute to determine if the chutes had a localized effect on sediment characteristics in the main channel. The difference in chute dynamics was tested by comparing the chute transects at one site with the chute transects at the other site (for example, UHAM-CH-OUT compared to GLOVR-CHOUT). Unlike the other comparisons, testing differences in chute dynamics could not be done using paired $t$-tests, and standard $t$-tests were used. Standard $t$-tests also were used to compare suspended-sediment data collected at the Missouri River at Sioux City, Iowa streamflow-gaging station (station ID 06486000) to suspended-sediment data collected at the Missouri River at Nebraska City, Nebr. streamflow-gaging station (station ID 06807000) (fig.1). Suspended-sediment concentration data from these streamflow-gaging stations were compared for the period of record, for the summer (May 1 thru Sept 30, 2008), and for just those days on which sampling was conducted at the nearby study site without accounting for differences in discharge.

Quality-control data (replicate samples) were analyzed for variability as the percent of deviation from the original sample ((sample - replicate)/sample * 100). This analysis gives an idea of just how variable data samples may be, even with the small number of quality-control samples.

\section{Suspended-and Streambed-Sediment Characteristics}

In this section of the report, results for each stated purpose are presented and discussed, following an initial summarization of results. The results indicate that the inlet structure does affect sediment characteristics within each chute. In contrast, changes in sediment characteristics within each chute and chute contributions to sediment characteristics of the Missouri River main channel were not significant at times when samples were collected. Likewise, no significant differences in suspended sediment were found between the two 
chutes, despite their differing dynamics. However, differences between chutes in streambed sediment were detected.

Samples were collected to characterize a range of streamflow conditions (table 2) in an effort to understand a wide range of sediment transport conditions within each chute. However, in early June 2008, the lower Missouri River, including the Upper Hamburg Bend reach, was carrying high flows that peaked at a discharge of $3,766 \mathrm{~m}^{3} / \mathrm{s}$ (U.S. Geological Survey, 2009). This flow is greater than a 5-year flood and less than a 10-year flood (based on analysis using PeakFQ [Flynn and others, 2006]), and the discharge is exceeded only 0.5 percent of the time in the streamflow record. Data collected during this high flow would have been valuable in understanding the extremes of sediment transport within the UHAM chute, but the sites during these conditions were unsafe, and access was not feasible. Samples were collected in early June 2008 at Glovers Point Bend during high-flow conditions (appendixes 1 and 2).

\section{Data Summaries}

In total, 51 suspended-sediment samples were collected, of which two were concurrent-replicate samples to evaluate field variability (table 2, appendix 1). Three samples

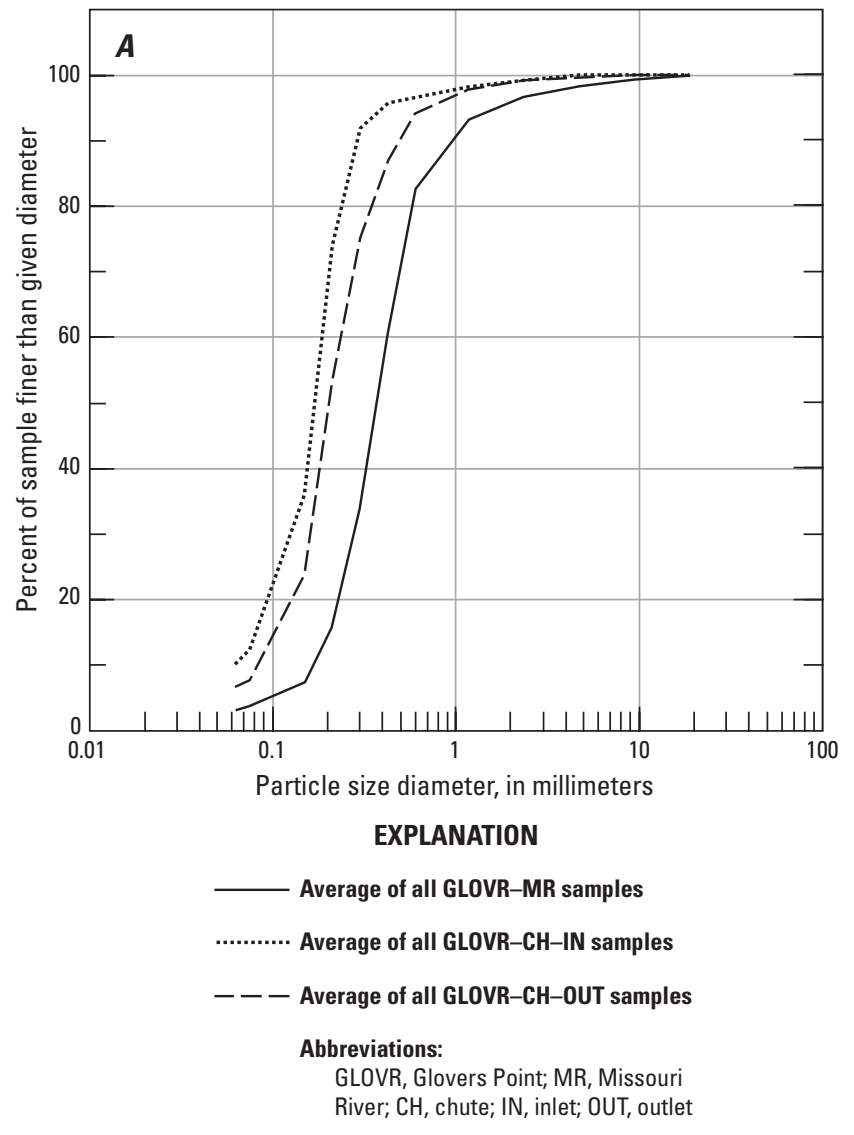

(including one of the replicates) were destroyed in shipment before analysis. Analytical results from the remaining replicate sample indicated variability of approximately 10 percent for total suspended-sediment concentration $\left(\mathrm{SSC}_{t}\right)$ and 8 percent for the fraction of sediment mass finer than sand (SF) (operationally defined here as particles finer than $0.0625 \mathrm{~mm}$ in diameter).

Forty-seven streambed samples were collected, including two concurrent replicates (table 2, appendix 2). Results from the two replicate samples indicated, on average, 10 percent variability in $\mathrm{d}_{50}$ and 26 percent variability in $\mathrm{d}_{84-16}$. In streambed-sediment samples, there was greater variabiity associated with coarser materials. Averaged (for all sample dates for a single transect) streambed grain-size distributions (GSD) were very similar with only two exceptions, the GLOVR chute GSD and the UHAM-CH-IN GSD (fig. 5). Averaged (for all sample dates for a single transect) grain-size distributions indicate mostly similar streambeds in the Missouri River, so one average is used to represent all three sampled Missouri River transects at each site. The chute transect that had a streambed GSD most similar to that of its corresponding main-channel transects was UHAM-CH-OUT (fig. 5). The graphical summary indicates that the average streambed GSD for both GLOVR chute transects was finer than the GLOVR

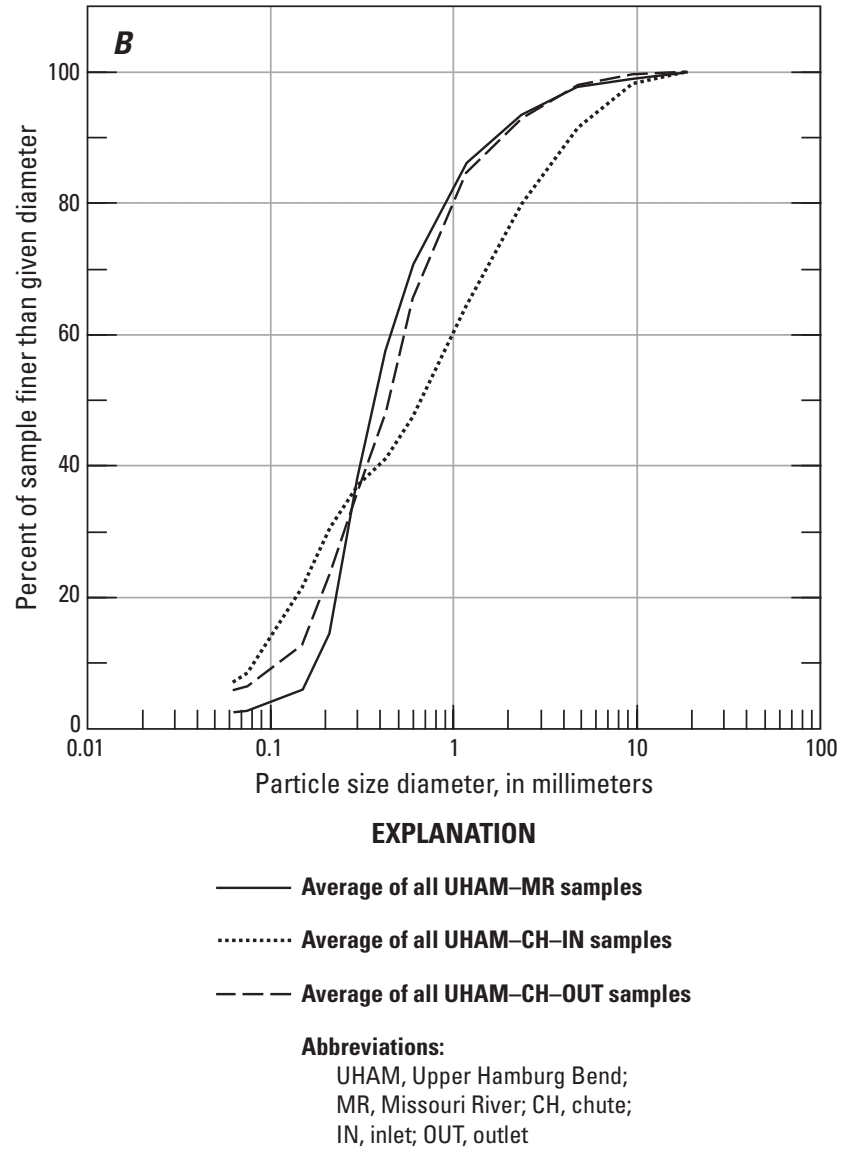

Figure 5. Averaged streambed grain-size distributions for each site sampled, Missouri River, 2008. 
main-channel transects. Additionally, the streambed at the inlet of the UHAM chute was more heterogeneous than all other transects. This is likely the result of a large depositional zone (created by slow-moving water comprising approximately one-fourth of the transect) along the northeastern end of the transect, and this transect probably is not representative of the chute as a whole.

\section{Comparative Analyses}

In general, the main detectable difference in sediment characteristics was related to the inlet structures' effect on the sediment supply within the chute. Comparisons of suspendedsediment concentrations from chute inlets to chute outlets did not reveal substantial erosive or depositional processes occurring in the chutes, though anecdotal evidence, such as photographs and observations, indicated otherwise. Photographs and observations at each chute following high-flow events documented substantial bank erosion and deposition within both chutes. Sediment transport in the main channel showed no dependence on chute processes. Suspended-sediment concentrations were similar in both chutes, but streambed-sediment size and heterogeneity were different. The streambed sediment in the UHAM chute was similar to that of the Missouri River main-channel streambed sediment.

The small number of samples constrained the statistical power to detect subtle differences. For example, given the measured variance in the data, figure 6 shows the magnitude of this constraint for $\mathrm{SSC}_{\mathrm{t}}$. The improvement in detectability of differences provided by the reduction of extraneous variance in comparisons made using paired-sample tests is shown in figure 6 .

\section{Inlet-Structure Effects on Sediment Distribution}

The inlet structures of both chutes reduced the supply of suspended sand entering chutes while leaving the supply of suspended particles finer than sand (particles finer than $0.0625 \mathrm{~mm}$ in diameter hereinafter called fines) unchanged in the water column (table 3 ). This result was expected based on the sediment transport theory, and because only water from the top of the main-channel water column will pass the inlet structures. The structures had no detectable effect on turbidity. This may indicate that, as measured in this study, turbidity was affected very little by the sand fraction of suspended sediment. The completion of hydrographic surveys in conjunction with the suspended- and streambed-sediment sampling would have added strength to the conclusions that the suspended-sand load was being reduced by the control structure and not by deposition within the chute at the inlet. However, comparisons of the Missouri River streambed upstream from chute inlets to the chute inlet streambed indicated that the inlet structure had no significant effect on grain-size distribution in deposited materials, the exception being an increase in grain-size heterogeneity in the UHAM chute (table 3). This result is likely an artifact of a nonrepresentatively located transect (UHAM-CH-IN). When streambed average GSD curves were examined, the GLOVR-CH streambed was on average finer than that of the Missouri River at GLOVR and at UHAM. However, the GLOVR-MR-US streambed was not significantly different from the GLOVR-CH-IN streambed when comparing $\mathrm{d}_{50}$, heterogeneity $\left(\mathrm{d}_{84-16}\right)$, or the fraction of sediment mass finer than sand (SF).

\section{Changes in Sediment Characteristics between the Inlet and Outlet of the Chute}

Although the chutes were designed to allow channel forming processes to evolve longitudinally as they approach equilibrium, only two of the statistical comparisons indicated significant differences in sediment characteristics between the transects at the inlet and outlet of the chutes at the time of sampling (table 3). Of the suspended-sediment characteristics tested, only $\mathrm{SSC}_{\mathrm{t}}$ for both sites pooled showed a significantly higher concentration at the outlet. The other significant difference was related to the aforementioned fines patch along the UHAM-CH-IN streambed. Nonetheless, there was physical evidence that channel evolution was occurring at both sites. For example, following a June 2008 flood event at the UHAM site, numerous examples of freshly eroded

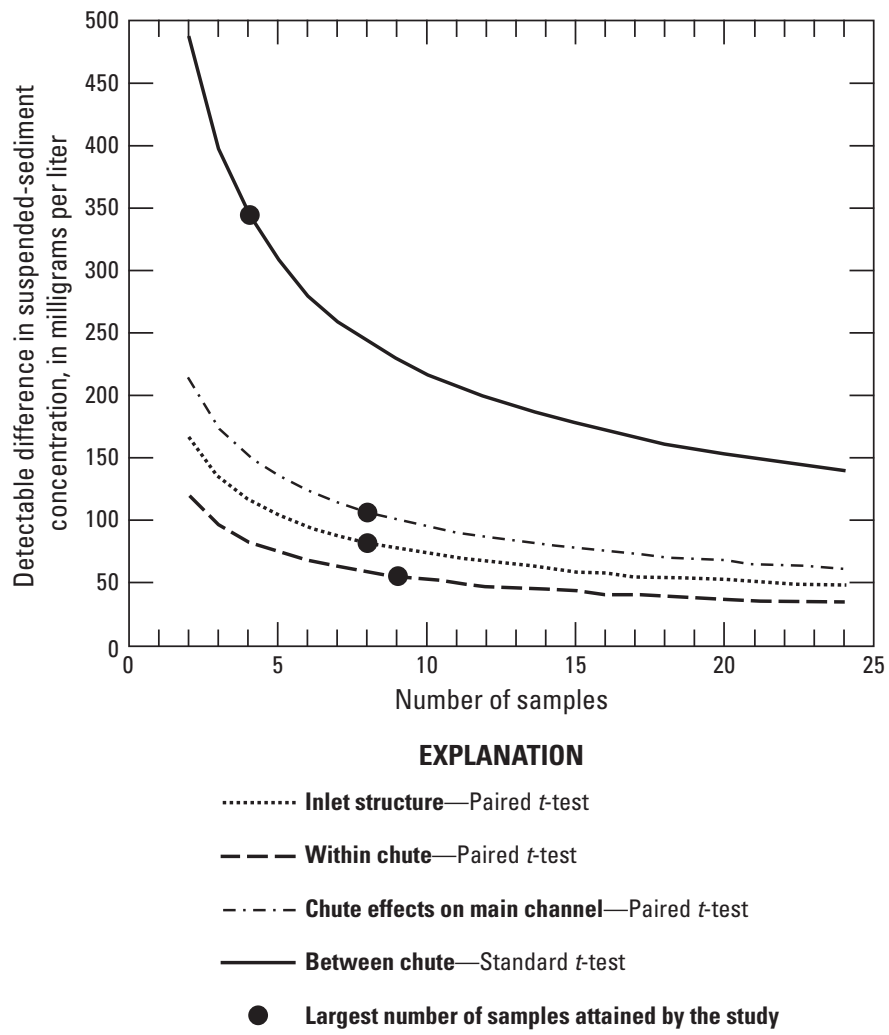

Figure 6. Relation of sample size to minimum detectable difference in suspended-sediment concentration for four groups of tested comparisons, Missouri River, 2008. 
Table 3. Summary of results from statistical comparisons made using paired $t$-tests, Missouri River, 2008.

[Transect groups represent a subset of transect-level data and may include both sites or each site individually; $<$ Site ID>-MR-MP at UHAM site refers to UHAM-MR-MP2; n, number of samples; $p$-value, probability value (italic); d, mean of differences between the paired groupings (group 1 - group 2); $\mathrm{SSC}_{\mathrm{t}}$, suspended-sediment concentration, total; $\mathrm{mg} / \mathrm{L}$, milligrams per liter; $\mathrm{SSC}_{<0.062}$, suspended-sediment concentration of particles finer than 0.062 millimeters $(\mathrm{mm})$ in diameter; $\mathrm{SSC}_{>0.062}$, suspended-sediment concentration of particles $0.062 \mathrm{~mm}$ or larger in diameter; SS SF, suspended-sediment fraction finer than sand, that is, finer than $0.062 \mathrm{~mm}$ in diameter; \%, percent; NTRU, nephelometric turbidity ratio units; $\mathrm{SSL}_{\mathrm{t}}$, suspended-sediment load, total; ton/d, tons per day; $\mathrm{SSL}_{>0.062}$, suspended-sediment load of particles $0.062 \mathrm{~mm}$ or larger in diameter; $\mathrm{SSL}_{<0.062}$, suspended-sediment load of particles finer than $0.062 \mathrm{~mm}$ in diameter; $\mathrm{d}_{50}$, median streambed diameter; $\mathrm{mm}$, millimeters; $\mathrm{d}_{84-16}$, difference in diameter between the 84th and 16th percentiles of the streambed grain-size distribution, in millimeters; SB SF, streambed sediment finer than sand; --, insignificant difference]

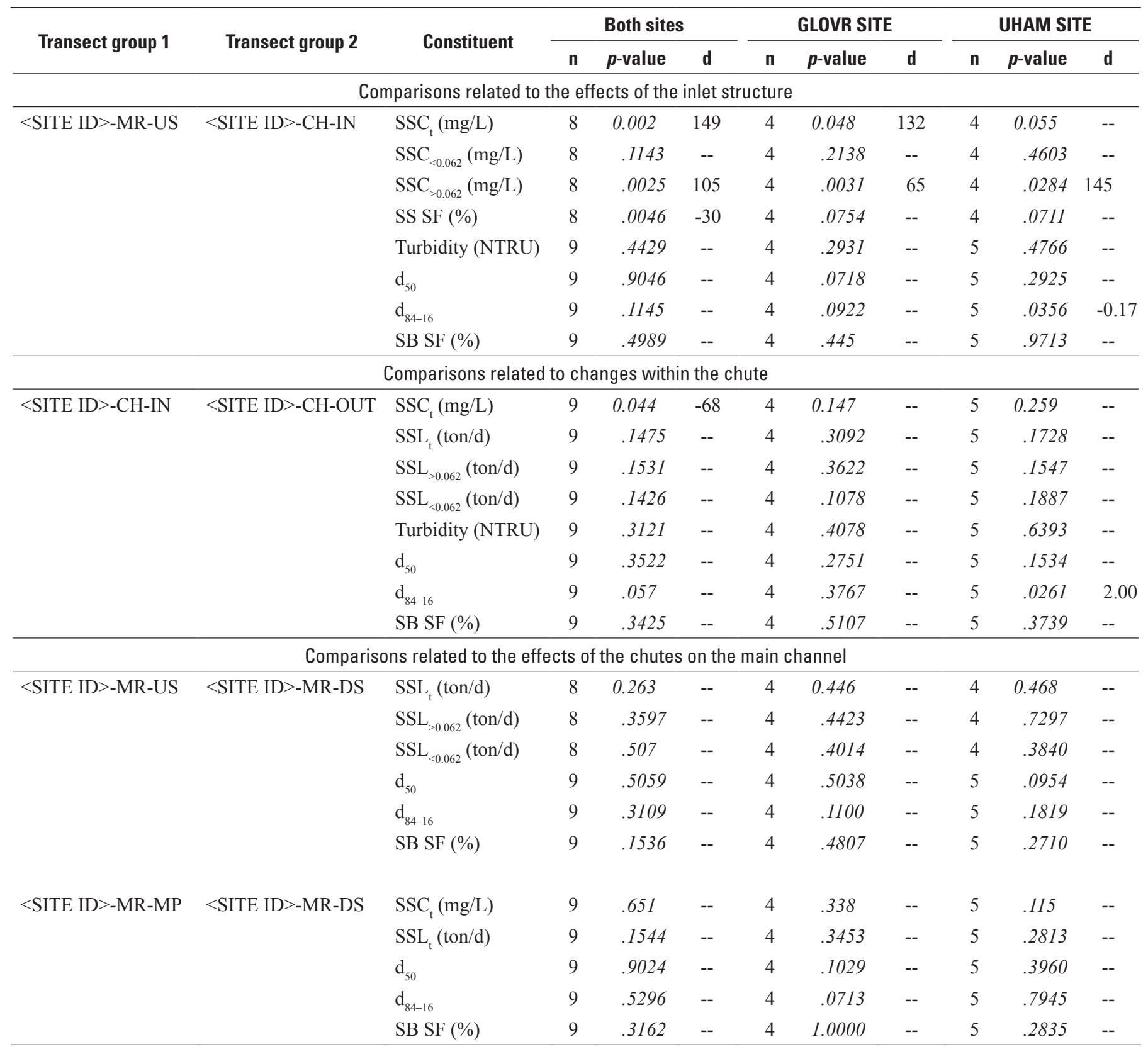


streambanks (fig. 7A) and freshly deposited sediment (fig. 7B) were observed in the chute. Additionally, $\mathrm{SSC}_{\mathrm{t}}$ and turbidity increased downstream along the GLOVR chute during the high-streamflow event measured on June 5, 2008, but showed less variability during lower streamflows (appendix 1).

The discrepancy between the measured data and the anecdotal evidence (fig. $7 A$ and $7 B$ ) indicates that the datasets may have been inadequate for these particular comparisons. Increasing the number of samples would have improved statistical robustness (fig. 6), but the data need to represent time periods in which geomorphic processes were active to more adequately characterize their effectiveness within the chutes. Many geomorphic processes, streambank erosion in particular, occur over short, discrete time intervals when energy thresholds are met (Schumm and others, 1984) rather than as continuous processes for which our sampling design was better suited. Localized events may further complicate the issue of geomorphic processes within Missouri River chutes. For example, localized rainfall (affecting an area of 259 square kilometers $\left[\mathrm{km}^{2}\right]$ around a chute) may saturate and erode chute streambanks but have a negligible effect on chute streamflow, which is regulated and drains an area that is three orders of magnitude larger. A more intensive study, including sediment sampling throughout and immediately following a large storm, may have discriminated differences related to sediment transport more successfully.

Though not reflected in the data compiled for this study, differences were observed between the two chutes that may have been related to the chute geometry, interior structure at the GLOVR site, and physical location in relation to the mainchannel and within the Missouri River system. During periods of high flow in the Missouri River, streamflow in parts of the

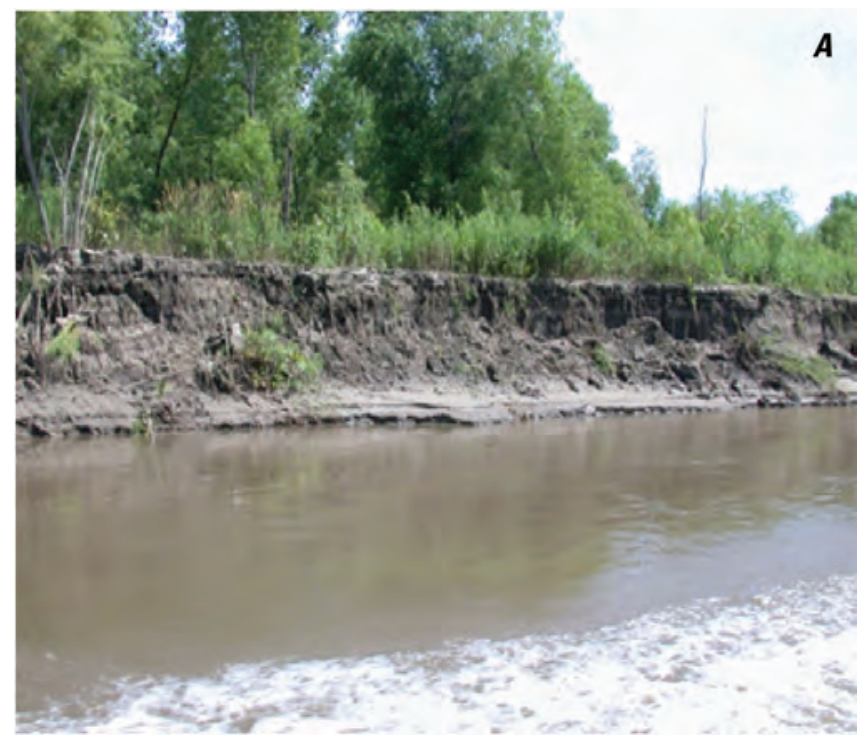

GLOVR chute could be characterized as backwater-affected, apparently caused by a short reach of anabranched channels of shallow, flowing water (fig. 3). The cause of this shallowness was not investigated in this study, but the reach appeared to be acting as a downstream control on streamflow in the chute during the study period. Assessing the hydraulic conditions of the chute was outside the scope of the sampling design, and further investigation of chute hydraulics at the GLOVR site is needed. In contrast, the UHAM site was characterized by freely flowing water (with the exception of the depositional zone along the left bank in the proximity of the inlet) as might be expected from partial upstream control by submerged weir conditions.

\section{Chute Effects on Sediment Characteristics in the Main Channel}

Although the effects of geomorphic processes in the chutes were inherently different from those of the main channel because of different dynamics and unprotected banks, the chutes had no detectable effect on the sediment characteristic in the main channel. This was true for the overall chute effect (main-channel comparisons between transects upstream and downstream from the chute) and the downstream effect of chute contributions into the main channel (main-channel comparisons between the midpoint transect and downstream transect), and for suspended-sediment and streambed characteristics (table 3 ). These results support the hypothesis that the sediment contributions from the chutes do not significantly affect the sediment budget of the Missouri River. However, the same limitations that applied to the analysis within the chutes also applied to these comparisons, albeit to a lesser extent,

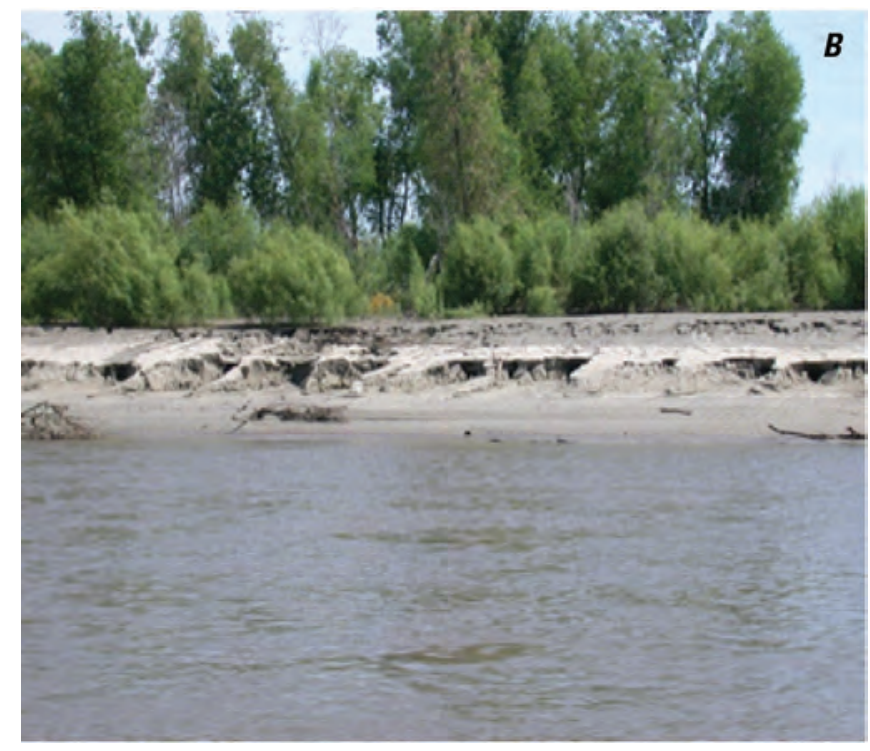

Figure 7. Photographs showing $(A)$ freshly eroded streambank and $(B)$ freshly deposited sediment in the Upper Hamburg Bend chute following a Missouri River flood event, June 2008. (Photographs by Dave Rus, U.S. Geological Survey.) 
because streamflow is so much greater in the main channel as compared to the chutes.

Suspended-sediment transport within the UHAM main channel did not appear to be affected by the left-bank chute inlet based on comparisons of suspended sediment in the main channel upstream and downstream from all chute inlets sampled. For the 10 pairs of samples collected and analyzed to bracket a chute inlet, there was no significant difference in any tested variable between the "upstream from inlet" set and the "downstream from inlet" set when data were pooled across sites. The tested variables were $\mathrm{SSC}_{\mathrm{t}}$, suspended-sand concentration $\left(\mathrm{SSC}_{>0.065}\right)$, percent of sediment finer than sand (SF), and turbidity.

\section{Chute Dynamics: Effect on Sediment Characteristics}

Chute dynamics refer to the energy-dissipation history and potential of each site; energy dissipation is a function of cumulative flow, chute design, chute location, hydrologic regime, source sediment supplies, and chute-bank materials. Comparisons between the sites to investigate differences in sediment characteristics that may indicate effects of different chute dynamics identified significant differences in streambed sediment but not suspended sediment (table 4). Differences in stream width and discharge also were tested because these physical attributes play a role in sediment transport and channel evolution. Wetted width and discharge varied significantly between the two chutes but not between the main channels (table 4, discharge not shown in table 4 because only one discharge measurement was made within the chute during each sampling trip). UHAM had greater stream width and much higher discharge (table 4).

None of the suspended-sediment characteristics $\left(\mathrm{SSC}_{\mathrm{t}}\right.$, $\mathrm{SF}$, and turbidity) were significantly different between the two chutes for any of the transect groups tested (table 4). These intersite comparisons focused on the chutes, but also included the upstream transects of the main channel to verify that differences between the two chutes were not a result of different suspended-sediment concentrations in the water being supplied to the chutes from the main channel. These main-channel comparisons indicated that the supply of suspended sediment was similar for both chutes. This was unexpected given that a large tributary, the Platte River, contributes sediment to the Missouri River between the sites (fig. 1). The USGS operates streamflow-gaging stations-Missouri River at Sioux City, Iowa (06486000), and Missouri River at Nebraska City, Nebr. (06807000) — relatively near the sampling sites where suspended-sediment samples are collected routinely (U.S. Geological Survey, 2009). Daily sediment data from these stream gages were analyzed to support and explain the above results. The Missouri River at Nebraska City typically had a much greater suspended-sediment concentration than did the Missouri River at Sioux City during the summer (May 1 through September 30) of 2008 as shown on figure 8. Samples collected from UHAM and GLOVR generally were similar in suspended-sediment concentrations to the streamflow-gaging station nearest the site, as shown on figure 8 . The suspendedsediment concentration measured in the Missouri River at GLOVR on June 5 was much higher than that measured at Sioux City, most likely because the Floyd River (not shown), which enters the Missouri between the Sioux City streamflowgaging station and the GLOVR study site, was contributing high flows. When suspended-sediment concentrations from the period of record (water years 1972 to 1976,1992 to 2000, and 2004 to 2008 at Sioux City and water years 1972 to 1976, and 1992 to 2008 at Nebraska City) at each streamflow-gaging station are compared using a standard $t$-test with unequal variance, the difference was significant ( $p$-value of 0 ). When daily suspended-sediment concentrations from the two streamflowgaging stations for the period May 1, 2008 through Sept 30, 2008 were compared using the standard $t$-test with unequal variance, the difference was again significant ( $p$-value of $\left.4.37 \times 10^{-11}\right)$. However, if the streamflow-gaging station data set is restricted to the days when sampling occurred at GLOVR and UHAM for this study, the $\mathrm{SSC}_{\mathrm{t}}$ at the two streamflowgaging stations was not different ( $p$-value of 0.24 using a standard $t$-test with unequal variance). These results verify that samples collected and analyzed for the study sites were representative, but because of when the samples were collected, the samples did not represent the longer-term difference in suspended-sediment concentrations between these Missouri River sites.

Though the fraction of fine particles in the streambed was similar at both chutes, there were significant differences in the overall GSD between the two chutes. Streambed $d_{50}$ at the UHAM chute, for the average of 10 samples collected at both transects combined, was $0.34 \mathrm{~mm}$ greater than that for the GLOVR chute, with an average of 8 samples collected at both transects. This result also was evident for separate comparisons of sample groupings for the transects near the inlet and outlet of the chutes (table 4). Comparisons of streambed $\mathrm{d}_{84-16}$ indicated that the UHAM chute was significantly more heterogeneous than was the GLOVR chute for the combined, outlet, and inlet data sets. As with suspended sediment, there was no significant difference in streambed sediment being supplied to each of the chutes based on comparisons between the two MR-US transects.

Though not tested explicitly, the streambed of the UHAM chute appeared to more closely resemble the main channel than did the GLOVR chute's streambed. This was further demonstrated by differences in the streambed GSD curves (fig. 5). For the two transects in the GLOVR chute, the shapes of the curves were similar to all the other nine transects sampled in the study but were shifted to the left, indicating a finer streambed with similar heterogeneity.

In addition to the sediment characteristics compared for the study, there were two clear differences observed in the physical characteristics of the chutes that likely played important roles in sediment transport - chute wetted width and streamflow. The UHAM chute was observed to be much 
Table 4. Summary of results from statistical comparisons used to understand the effect of chute dynamics on sediment characteristics, Missouri River, 2008.

[UHAM, Upper Hamburg Bend; GLOVR, Glovers Point Bend; CH, Chute; IN, inlet; OUT, outlet; COMB, combined inlet and outlet; n1, number of samples from UHAM site; n2, number of samples from GLOVR site; $p$-value, probability value (italic); d, mean of differences between the sites (group listed first - group listed second); SSC, suspended-sediment concentration, total; mg/L, milligrams per liter; SS SF, suspended sediment finer than sand, that is, finer than $0.062 \mathrm{~mm}$ in diameter; $\%$, percent; $\mathrm{d}_{50}$, median streambed sediment diameter; mm, millimeters; $d_{84-16}$, difference in diameter between the 84 th and 16th percentiles of the streambed grain-size distribution; SB SF, streambed sediment finer than sand; NTRU, nephelometric turbidity ratio units; ft, feet; --, insignificant difference]

\begin{tabular}{|c|c|c|c|c|c|c|c|c|c|c|c|c|c|c|c|c|}
\hline \multirow[t]{2}{*}{ Constituent } & \multicolumn{4}{|c|}{$\begin{array}{l}\text { UHAM-CH-IN compared to } \\
\text { GLOVR-CH-IN }\end{array}$} & \multicolumn{4}{|c|}{$\begin{array}{l}\text { UHAM-CH-OUT compared to } \\
\text { GLOVR-CH-OUT }\end{array}$} & \multicolumn{4}{|c|}{$\begin{array}{c}\text { UHAM-CH-COMB compared to } \\
\text { GLOVR-CH-COMB }\end{array}$} & \multicolumn{4}{|c|}{$\begin{array}{l}\text { UHAM-MR-US compared to } \\
\text { GLOVR-MR-US }\end{array}$} \\
\hline & n1 & n2 & $p$-value & d & n1 & n2 & $p$-value & d & n1 & n2 & $p$-value & d & n1 & n2 & $p$-value & d \\
\hline $\mathrm{SSC}_{\mathrm{t}}(\mathrm{mg} / \mathrm{L})$ & 5 & 4 & 0.904 & -- & 5 & 4 & 0.970 & -- & 10 & 8 & 0.956 & -- & 4 & 4 & 0.694 & -- \\
\hline SS SF (\%) & 5 & 4 & .7016 & -- & 5 & 4 & .3057 & -- & 10 & 8 & .2645 & -- & 4 & 4 & .9180 & -- \\
\hline Turbidity (NTRU) & 5 & 4 & .7064 & -- & 5 & 4 & .6600 & -- & 10 & 8 & .5162 & -- & 5 & 4 & .6164 & -- \\
\hline $\mathrm{d}_{50}(\mathrm{~mm})$ & 5 & 4 & .0340 & 0.47 & 5 & 4 & .0437 & 0.20 & 10 & 8 & .0027 & 0.34 & 5 & 4 & .2379 & -- \\
\hline $\mathrm{d}_{84-16}(\mathrm{~mm})$ & 5 & 4 & .0080 & 2.97 & 5 & 4 & .0202 & .88 & 10 & 8 & .0021 & 1.83 & 5 & 4 & .0805 & -- \\
\hline SB SF $(\%)$ & 5 & 4 & .4968 & -- & 5 & 4 & .8375 & -- & 10 & 8 & .4651 & -- & 5 & 4 & .7274 & -- \\
\hline Wetted width (ft) & 5 & 4 & .0002 & 248 & 5 & 4 & .0363 & 68 & 10 & 8 & .0001 & 158 & 5 & 4 & .0679 & -- \\
\hline
\end{tabular}




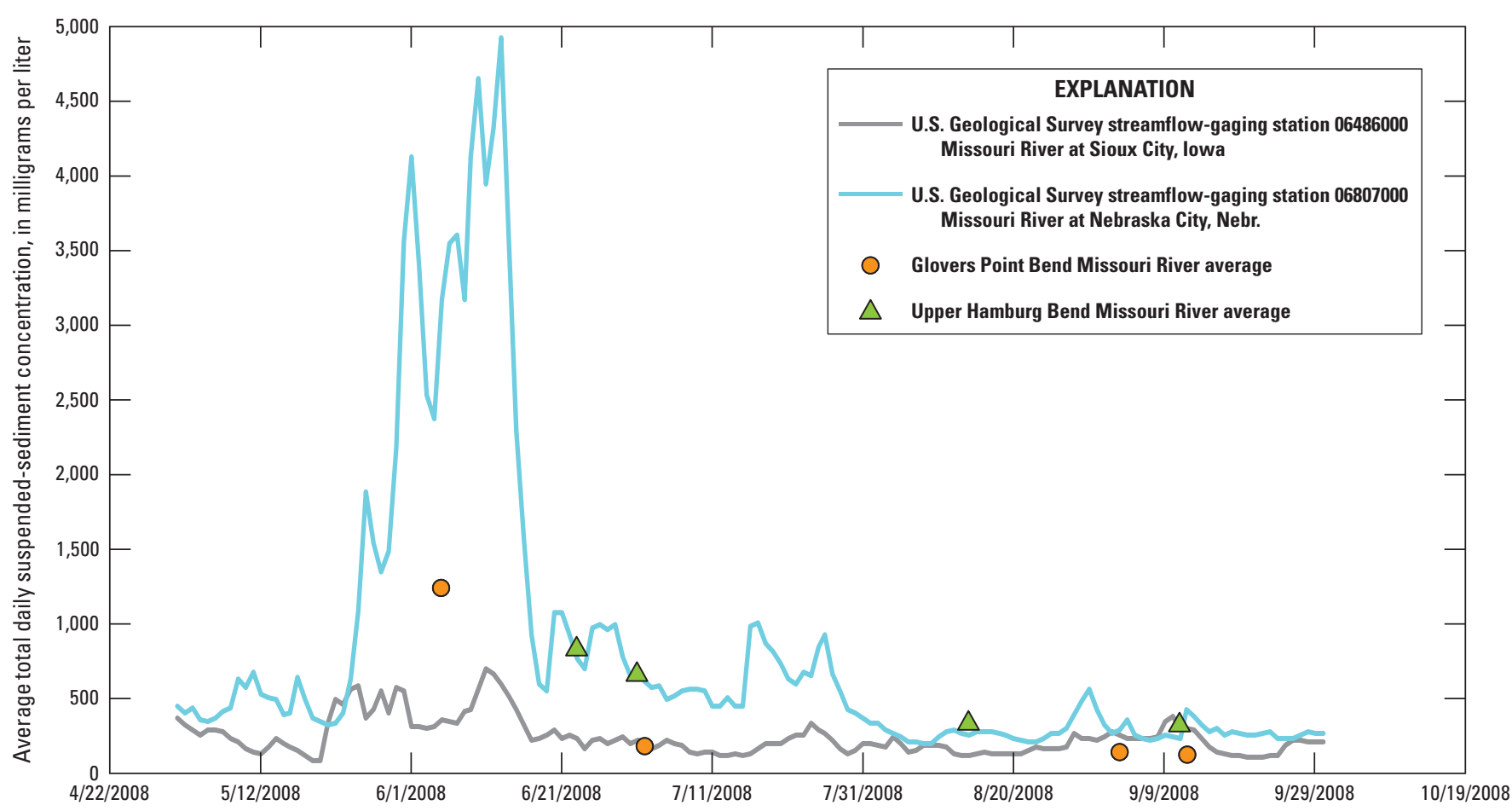

Figure 8. Daily suspended-sediment concentration, Missouri River at Sioux City, lowa, and Missouri River at Nebraska City, Nebr., and discretely sampled concentrations measured for this study, May 2008 through September 2008.

wider than the GLOVR chute. Though wetted width measurements were collected at each transect, as required for discharge and water-quality sampling, these widths may not be representative of the average width throughout the chute. Nonetheless, the UHAM chute was found to be significantly wider than the GLOVR chute (table 4). Streamflow also was significantly greater ( $p$-value of 0.0293 , not shown in table 4 because only one discharge measurement was made within the chute during each sampling trip) at the UHAM chute than the GLOVR chute. At $106 \mathrm{~m}^{3} / \mathrm{s}$, streamflow in the UHAM chute was more than 19 times greater, on average, than the GLOVR chute. The percentage of main-channel streamflow entering each chute was different between the two sites as well. At the GLOVR study site, the greatest percentage of upstream flow diverted into the chute was 1.33 percent on June 6,2008 , when the main channel was carrying $782 \mathrm{~m}^{3} / \mathrm{s}$ and the chute was carrying $10.4 \mathrm{~m}^{3} / \mathrm{s}$. GLOVR chute carried from 0.14 to 1.33 percent $(1.33,0.14,0.88$, and 0.54 percent on June 5, July 2, September 3, and September 12, respectively) of the main-channel flow. The greatest percentage of upstream flow diverted into the UHAM chute was 15.6 percent, on June 23, 2008 , when the main channel was carrying $1,104 \mathrm{~m}^{3} / \mathrm{s}$ and the chute was carrying $172 \mathrm{~m}^{3} / \mathrm{s}$. UHAM chute carried from 1.03 to 15.6 percent $(15.6,14.4,11.4,9.15$, and 1.03 percent on June 23, July 1, August 14, September 11, and November 25, respectively) of the main-channel flow measured for these sampling events.
As demonstrated by differences in streambed material, width, and streamflow, the chute dynamics at UHAM more closely resembled the main channel than those characteristics at GLOVR in the specific parameters measured. This may reflect the greater amount of geomorphic work or energy dissipated throughout the years of operation of the UHAM chute as compared to the GLOVR chute. However, these differences also could be explained by differences in chute design, water or sediment supply, or differences in location and streambank materials that affect the amount of geomorphic work done within a chute.

\section{Summary and Conclusions}

The U.S. Army Corps of Engineers has constructed 17 off-channel chutes along the channelized Missouri River to increase shallow water habitat that has been lost. Currently, 2008 , there are many uncertainties concerning the functioning of these chute projects. This research investigated specific aspects of chute design and function in relation to sediment characteristics including: (1) the effects of inlet structures; (2) changes occurring within the chutes; (3) the effects of chutes on sediment characteristics in the main channel; and (4) differences in chute dynamics between the two chutes. The effect of side-channel chutes on sediment transport in the 
Missouri River was studied for two sites located on the lower Missouri River at Upper Hamburg Bend near Nebraska City, Nebr. (UHAM), and at Glovers Point Bend near Winnebago, Nebr. (GLOVR). Each site was characterized using a minimum of five sampling transects (two in the chute and three in the main channel) designed to bracket sediment exchanges between the chutes and the main channel. A sixth transect was included at the UHAM site to bracket a nontarget chute inlet midway between the primary chute inlet and outlet. Gradecontrol structures at UHAM have recently (2009) been modified, so results for 2008 sampling may no longer adequately describe sediment characteristics at this site.

A temporal series of representative water and streambedsediment samples were collected at each transect in conjunction with streamflow and turbidity measurements between June and November 2008. Five sample sets were collected at the UHAM site and four sample sets were collected at the GLOVR site. Water samples were analyzed for total suspended-sediment concentration and for the sediment fraction finer than 0.062 millimeters, and streambed samples were analyzed for grain-size distribution. Paired $t$-tests and standard $t$-tests were used to compare sets of transects grouped according to the respective purposes of the study.

As expected, the suspended-sediment supply at the inlet structure from the top part of the main-channel water column reduced the amount of coarse suspended sediments while leaving the fine sediments unaffected in the chutes. Despite significant differences in suspended-sediment concentration $\left(\mathrm{SSC}_{\mathrm{t}}\right)$ and suspended-sand concentration $\left(\mathrm{SSC}_{>0.062}\right)$ between the main-channel transects upstream from the chute (MR-US) and chute inlets, bed material median size did not differ. Statistical results did not indicate differences between the inlets and outlets of the chutes; however, evidence of recent channel evolution was observed in both chutes. The insignificant effect of the chutes on sediment characteristics of the main channel was probably related to the much greater streamflow of the Missouri River main channel as compared to the chutes. There were no significant differences in the suspended-sediment characteristics between the two sites. Differences in chute dynamics at the UHAM site led to a coarser streambed, greater wetted width, and much greater streamflow in the chute than at the GLOVR site. U.S. Geological Survey daily suspended-sediment data from nearby streamflow-gaging stations indicated that suspended-sediment concentrations are typically different between the study sites, as would be expected because of intervening large tributaries such as the Platte River. However, when streamflow-gaging-station sediment data were compared only for those days when samples were collected at the UHAM and GLOVR study sites, there was no detectable difference between the sites.

The main difference detected by this study was that suspended sediment at the chute inlets was finer than that of the Missouri River main channel upstream of the inlets. It was concluded that the inlet structures have a significant effect on the sediment supply to the chutes. In addition, the results indicated that the chutes had little effect on the sediment characteristics in the main channel. In general, there were few differences detected that were not already expected based on sediment-transport theory. However, several expected differences (based on theory or field observations) were not detected by the statistical comparisons, mainly differences in $\mathrm{SSC}_{\mathrm{t}}$ between the chute inlets and outlets when data were tested for each site separately, as well as, differences in $\mathrm{SSC}_{\mathrm{t}}$ between the main channel at UHAM compared to $\mathrm{SSC}_{\mathrm{t}}$ in the main channel at GLOVR. This discrepancy may have been the result of a small number of samples, the timing of samples, and the samples representing different portions of the hydrograph that could be remedied by continued monitoring of these sites under the same sample design with a focus on sampling during events.

\section{References Cited}

Barneveld, H.J., Nieuwkamer, R.L.J., and Klaassen, G.J., 1994, Secondary channels - Opportunities for and limitations of habitat restoration: Water Science and Technology, v. 29 , no. 3 , p. 335-345.

Davis, B.E., 2005, A guide to the proper selection and use of federally approved sediment and water-quality samplers: U.S. Geological Survey Open-File Report 2005-1087, 20 p.

Edwards, T.K., and Glysson, G.D., 1999, Field methods for measurement of fluvial sediment: U.S. Geological Survey Techniques of Water-Resources Investigations, book 3, chap. C2, 89 p.

Flynn, K.M., Kirby, W.H., and Hummel, P.R., 2006, User's manual for program PeakFQ, Annual Flood Frequency Analysis Using Bulletin 17B Guidelines: U.S. Geological Survey Techniques and Methods, book 4, chap. B4, 42 p.

Guy, H.P., 1969, Laboratory theory and methods for sediment analysis: U.S. Geological Survey Techniques of WaterResources Investigations, book 5, chap. Cl, 58 p.

Horowitz, A.J., 2008, Determining annual suspended sediment and sediment-associated trace element and nutrient fluxes: Science of the Total Environment, v. 400, p. 315-343.

Jacobson, R.B., Johnson, H.E., Laustrup, M.S., D’Urso, G.J., and Reuter, J.M., 2004, Physical habitat dynamics in four side-channel chutes, Lower Missouri River: U.S. Geological Survey Open-File Report 2004-1071, 66 p.

Mueller, D.S., and Wagner, C.R., 2008, Measuring discharge with acoustic Doppler current profilers from a moving boat: U.S. Geological Survey Techniques and Methods, chap. 3A-22, 73 p. 
Oberg, K.A., Morlock, S.E., and Caldwell, W.S., 2005, Quality-assurance plan for discharge measurements using acoustic Doppler current profilers: U.S. Geological Survey Scientific Investigations Report 2005-5183, 35 p.

Ott, R.L., and Longnecker, Michael, 2001, An introduction to statistical methods and data analysis (5th ed.): Pacific Grove, Calif., Duxbury, 1,152 p.

Schropp, M.H.I., 1995, Principles of designing secondary channels along the River Rhine for the benefit of ecological restoration: Water Science and Technology, v. 31, no. 8, p. 379-382.

Schumm, S.A., Harvey, M.D., and Watson, C.C., 1984, Incised Channels-Morphology, Dynamics and Control: Littleton, Colo., Water Resources Publications, 200 p.

Shields, R.D., Jr., and Abt, S.T., 1989, Sediment deposition in cutoff meander bends and implications for effective management-Regulated Rivers: Research \& Management, v. 4, p. 381-396.

Slingerland, Rudy, and Smith, N.D., 1998, Necessary conditions for a meandering-river avulsion: Geology, v. 26, no. 5, p. $435-438$.

U.S. Fish and Wildlife Service, 2000, Biological opinion on the operation of the Missouri River main stem reservoir system, operation and maintenance of the Missouri River bank stabilization and navigation project, and operation of the Kansas River reservoir system: Minneapolis, Minn., U.S. Fish and Wildlife Service, 286 p.

U.S. Geological Survey, 2009, USGS Surface-water data for the Nation, http://waterdata.usgs.gov/nwis/sw, accessed November 1, 2009.

U.S. Geological Survey, variously dated, National field manual for the collection of water-quality data: U.S. Geological Survey Techniques of Water-Resources Investigations, book 9, chaps. A1-A9, accessed December 15, 2009 at http://pubs.water.usgs.gov/twri9A. (Chapter updates and revisions are ongoing and are summarized at $h$ ttp://water. usgs.gov/owq/FieldManual/mastererrata.html).

Van Rijn, L.C., 1984, Sediment transport—Part II, Suspended load transport: Journal of Hydraulic Engineering, v. 110, no. 11, p. 1,613-1,641. 


\section{Appendixes}


Appendix 1. Suspended sediment Upper Hamburg and Glovers Point Bends, Missouri River, 2008.

[STAID, station identification number; yyyymmdd, date format in 4-digit year, 2-digit month, and 2-digit day; hhmm, 24-hour time format in 2-digit hour and 2-digit minute; USGS National Water Information System parameter numbers given in parentheses; +/-, plus or minus; nm, nanometer; NTRU, nephelometric turbidity ratio units; R, River; NE, Nebraska; --, not measured; EWI, equal width increment; b, sample container broken during shipment prior to analysis]

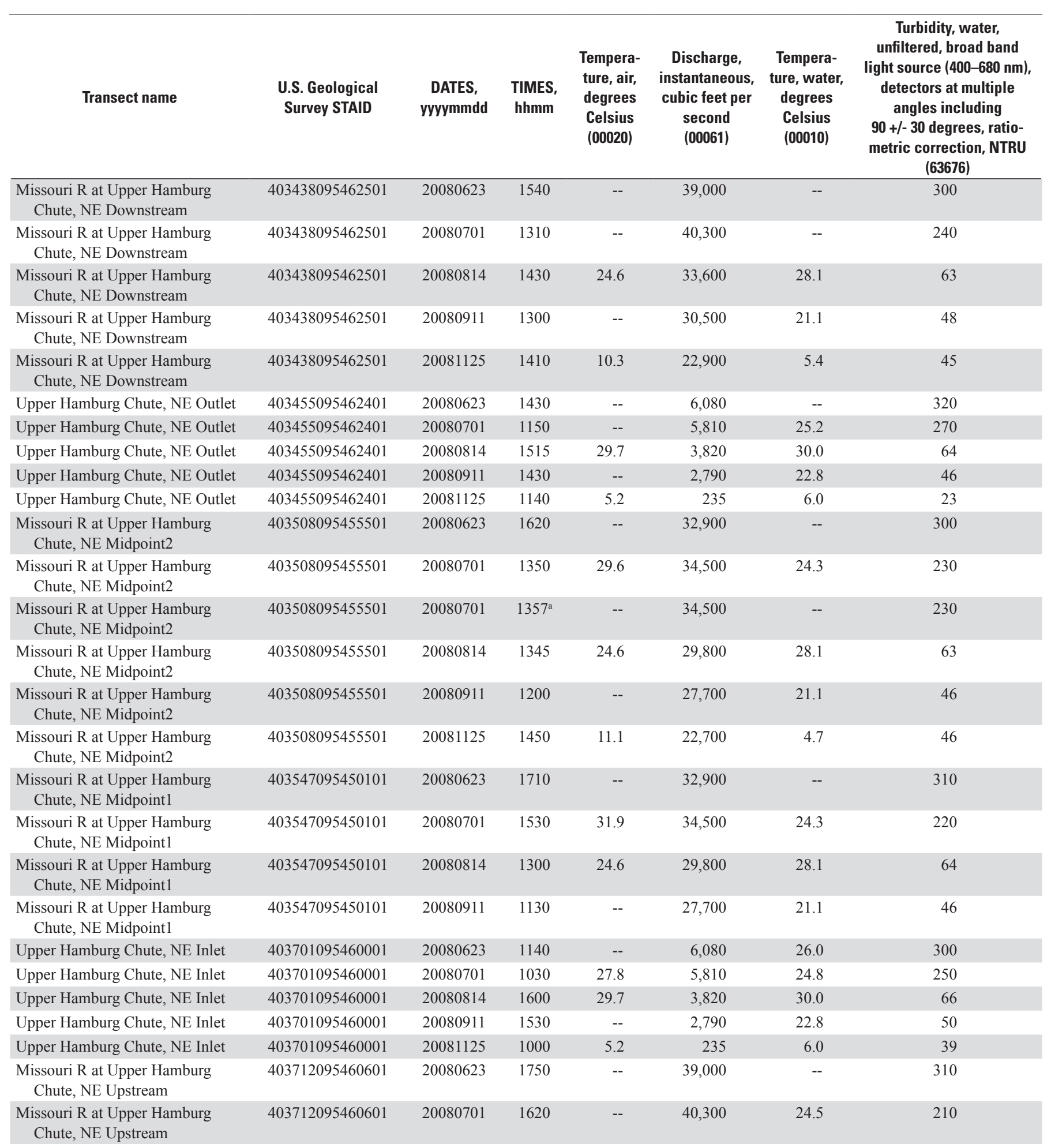




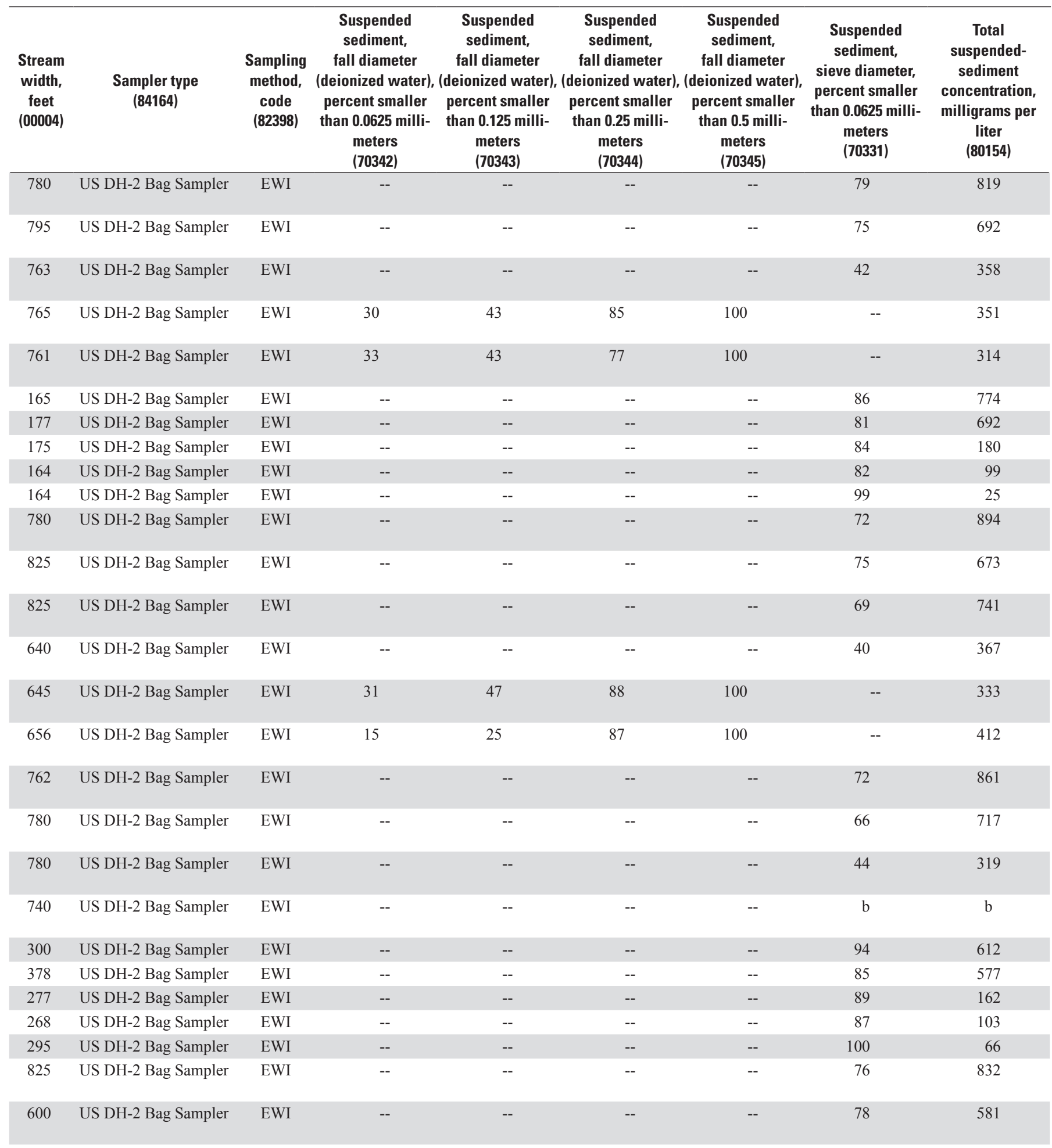


Appendix 1. Suspended sediment Upper Hamburg and Glovers Point Bends, Missouri River, 2008.-Continued

[STAID, station identification number; yyyymmdd, date format in 4-digit year, 2-digit month, and 2-digit day; hhmm, 24-hour time format in 2-digit hour and 2-digit minute; USGS National Water Information System parameter numbers given in parentheses; +/-, plus or minus; NTRU, nephelometric turbidity ratio units; R, River; NE, Nebraska; --, not measured; EWI, equal width increment; b, sample container broken during shipment prior to analysis]

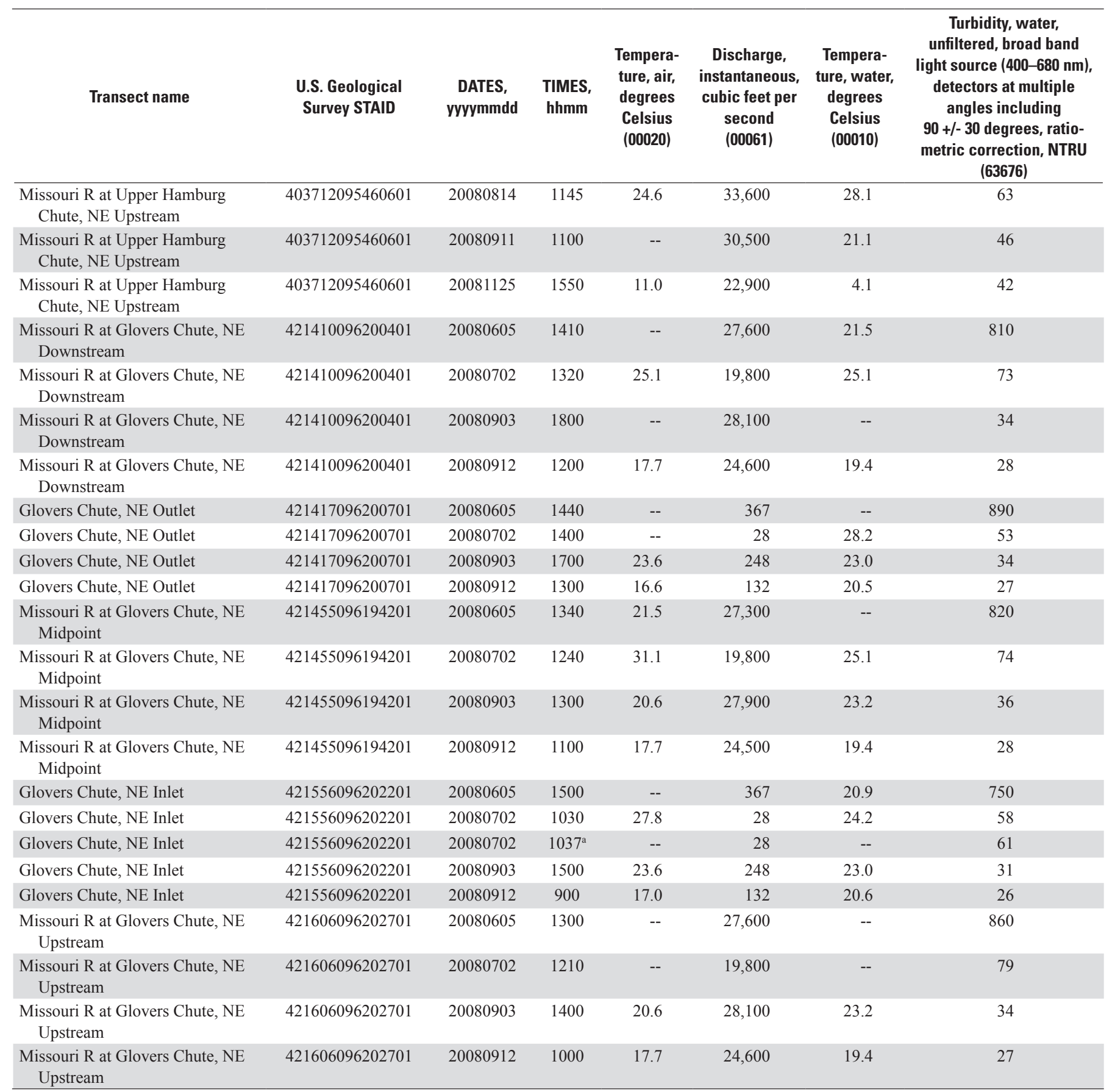

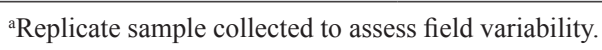




\begin{tabular}{|c|c|c|c|c|c|c|c|c|}
\hline $\begin{array}{c}\text { Stream } \\
\text { width, } \\
\text { feet } \\
(00004)\end{array}$ & $\begin{array}{c}\text { Sampler type } \\
\text { (84164) }\end{array}$ & $\begin{array}{c}\text { Sampling } \\
\text { method, } \\
\text { code } \\
\text { (82398) }\end{array}$ & $\begin{array}{c}\text { Suspended } \\
\text { sediment, } \\
\text { fall diameter } \\
\text { (deionized water), } \\
\text { percent smaller } \\
\text { than } 0.0625 \text { milli- } \\
\text { meters } \\
\text { (70342) }\end{array}$ & $\begin{array}{c}\text { Suspended } \\
\text { sediment, } \\
\text { fall diameter } \\
\text { (deionized water), } \\
\text { percent smaller } \\
\text { than } 0.125 \text { milli- } \\
\text { meters } \\
\text { (70343) }\end{array}$ & $\begin{array}{c}\text { Suspended } \\
\text { sediment, } \\
\text { fall diameter } \\
\text { (deionized water), } \\
\text { percent smaller } \\
\text { than } 0.25 \text { milli- } \\
\text { meters } \\
(70344) \\
\end{array}$ & $\begin{array}{c}\text { Suspended } \\
\text { sediment, } \\
\text { fall diameter } \\
\text { (deionized water), } \\
\text { percent smaller } \\
\text { than } 0.5 \text { milli- } \\
\text { meters } \\
\text { (70345) }\end{array}$ & $\begin{array}{l}\text { Suspended } \\
\text { sediment, } \\
\text { sieve diameter, } \\
\text { percent smaller } \\
\text { than } 0.0625 \text { milli- } \\
\text { meters } \\
\text { (70331) }\end{array}$ & $\begin{array}{c}\text { Total } \\
\text { suspended- } \\
\text { sediment } \\
\text { concentration, } \\
\text { milligrams per } \\
\text { liter } \\
\text { (80154) }\end{array}$ \\
\hline 675 & US DH-2 Bag Sampler & EWI & -- & -- & -- & -- & $\mathrm{b}$ & $\mathrm{b}$ \\
\hline 755 & US DH-2 Bag Sampler & EWI & 45 & 60 & 93 & 100 & -- & 297 \\
\hline 690 & US D-96 Bag Sampler & EWI & -- & -- & -- & -- & 69 & 1,480 \\
\hline 650 & US DH-2 Bag Sampler & EWI & 40 & 57 & 87 & 100 & -- & 127 \\
\hline 120 & US D-96 Bag Sampler & EWI & -- & -- & -- & -- & 97 & 1,040 \\
\hline 44 & Sampler US DH-48 & EWI & -- & -- & -- & -- & 42 & 298 \\
\hline 125 & Sampler US DH-48 & EWI & -- & -- & -- & -- & 82 & 67 \\
\hline 115 & Sampler US DH-48 & EWI & -- & -- & -- & -- & 66 & 55 \\
\hline 630 & US D-96 Bag Sampler & EWI & -- & -- & -- & -- & 92 & 1,110 \\
\hline 600 & US DH-2 Bag Sampler & EWI & -- & -- & -- & -- & 78 & 166 \\
\hline 673 & US DH-2 Bag Sampler & EWI & 49 & 65 & 78 & 100 & -- & 135 \\
\hline 58 & US DH-2 Bag Sampler & EWI & -- & -- & -- & -- & 91 & 39 \\
\hline 750 & US D-96 Bag Sampler & EWI & -- & -- & -- & -- & 93 & 1,140 \\
\hline 600 & US DH-2 Bag Sampler & EWI & -- & -- & -- & -- & 68 & 199 \\
\hline 704 & US DH-2 Bag Sampler & EWI & 47 & 64 & 88 & 100 & -- & 141 \\
\hline 639 & US DH-2 Bag Sampler & EWI & 36 & 48 & 70 & 100 & -- & 141 \\
\hline
\end{tabular}


Appendix 2. Streambed sediment Upper Hamburg and Glovers Point Bends, Missouri River, 2008.

[STAID, station identification number; yyyymmdd, date format in 4-digit year, 2-digit month, and 2-digit day; hhmm, 24-hour time format in 2-digit hour and 2-digit minute; USGS National Water Information System parameter numbers given in parentheses; R, river; NE, Nebraska; --, not measured]

\begin{tabular}{|c|c|c|c|c|c|c|c|c|c|}
\hline Transect name & $\begin{array}{l}\text { U.S. Geological } \\
\text { Survey STAID }\end{array}$ & $\begin{array}{c}\text { DATES, } \\
\text { yyyymmdd }\end{array}$ & $\begin{array}{l}\text { TIMES, } \\
\text { hhmm }\end{array}$ & $\begin{array}{l}\text { Discharge, } \\
\text { instantaneous, } \\
\text { cubic feet per } \\
\text { second } \\
\text { (00061) }\end{array}$ & $\begin{array}{l}\text { Stream } \\
\text { width, } \\
\text { feet } \\
(00004)\end{array}$ & $\begin{array}{l}\text { Sampler } \\
\text { type } \\
(84164)\end{array}$ & $\begin{array}{l}\text { Bed sediment, } \\
\text { dry sieved; } \\
\text { sieve diameter, } \\
\text { percent smaller } \\
\text { than } 0.0625 \text { mil- } \\
\text { limeters } \\
\text { (80164) }\end{array}$ & $\begin{array}{l}\text { Bed sediment, } \\
\text { dry sieved; } \\
\text { sieve diameter, } \\
\text { percent smaller } \\
\text { than } 0.075 \text { mil- } \\
\text { limeters } \\
\text { (69075) }\end{array}$ & $\begin{array}{l}\text { Bed sediment, } \\
\text { dry sieved; } \\
\text { sieve diameter, } \\
\text { percent smaller } \\
\text { than } 0.15 \text { mil- } \\
\text { limeters } \\
\text { (69073) }\end{array}$ \\
\hline $\begin{array}{l}\text { Missouri R at Upper } \\
\text { Hamburg Chute, NE } \\
\text { Downstream }\end{array}$ & 403438095462501 & 20080623 & 1520 & 39,000 & 780 & US BM-54 & 0 & 0 & 5 \\
\hline $\begin{array}{l}\text { Missouri R at Upper } \\
\text { Hamburg Chute, NE } \\
\text { Downstream }\end{array}$ & 403438095462501 & 20080701 & 1250 & 40,300 & 795 & US BM-54 & 1 & 1 & 10 \\
\hline $\begin{array}{l}\text { Missouri R at Upper } \\
\text { Hamburg Chute, NE } \\
\text { Downstream }\end{array}$ & 403438095462501 & 20080814 & 1830 & 33,600 & 763 & US BM-54 & 0 & 0 & 1 \\
\hline $\begin{array}{l}\text { Upper Hamburg Chute, } \\
\text { NE Outlet }\end{array}$ & 403455095462401 & 20080623 & 1450 & 6,080 & 165 & US BM-54 & 4 & 4 & 7 \\
\hline $\begin{array}{l}\text { Upper Hamburg Chute, } \\
\text { NE Outlet }\end{array}$ & 403455095462401 & 20080701 & 1210 & 5,810 & 177 & US BM-54 & 1 & 1 & 3 \\
\hline $\begin{array}{l}\text { Upper Hamburg Chute, } \\
\text { NE Outlet }\end{array}$ & 403455095462401 & 20080814 & 1845 & 3,820 & 175 & US BM-54 & 4 & 5 & 12 \\
\hline $\begin{array}{l}\text { Upper Hamburg Chute, } \\
\text { NE Outlet }\end{array}$ & 403455095462401 & 20080911 & 1430 & 2,790 & 164 & US BM-54 & 10 & 11 & 25 \\
\hline $\begin{array}{l}\text { Upper Hamburg Chute, } \\
\text { NE Outlet }\end{array}$ & 403455095462401 & 20081125 & 1200 & 235 & 164 & US BM-54 & 10 & 11 & 17 \\
\hline $\begin{array}{l}\text { Missouri R at Upper } \\
\text { Hamburg Chute, NE } \\
\text { Midpoint2 }\end{array}$ & 403508095455501 & 20080814 & 1815 & 29,800 & 640 & US BM-54 & 0 & 0 & 1 \\
\hline $\begin{array}{l}\text { Missouri R at Upper } \\
\text { Hamburg Chute, NE } \\
\text { Midpoint } 2\end{array}$ & 403508095455501 & 20080911 & 1200 & 27,700 & 645 & US BM-54 & 0 & 0 & 1 \\
\hline $\begin{array}{l}\text { Missouri R at Upper } \\
\text { Hamburg Chute, NE } \\
\text { Midpoint2 }\end{array}$ & 403508095455501 & 20081125 & 1500 & 22,700 & 656 & US BM-54 & 0 & 0 & 0 \\
\hline $\begin{array}{l}\text { Upper Hamburg Chute, } \\
\text { NE Inlet }\end{array}$ & 403701095460001 & 20080623 & 1210 & 6,080 & 300 & US BM-54 & 4 & 5 & 18 \\
\hline $\begin{array}{l}\text { Upper Hamburg Chute, } \\
\text { NE Inlet }\end{array}$ & 403701095460001 & 20080701 & 1020 & 5,810 & 378 & US BM-54 & 0 & 0 & 1 \\
\hline $\begin{array}{l}\text { Upper Hamburg Chute, } \\
\text { NE Inlet }\end{array}$ & 403701095460001 & 20080814 & 1630 & 3,820 & 277 & US BM-54 & 7 & 8 & 17 \\
\hline
\end{tabular}




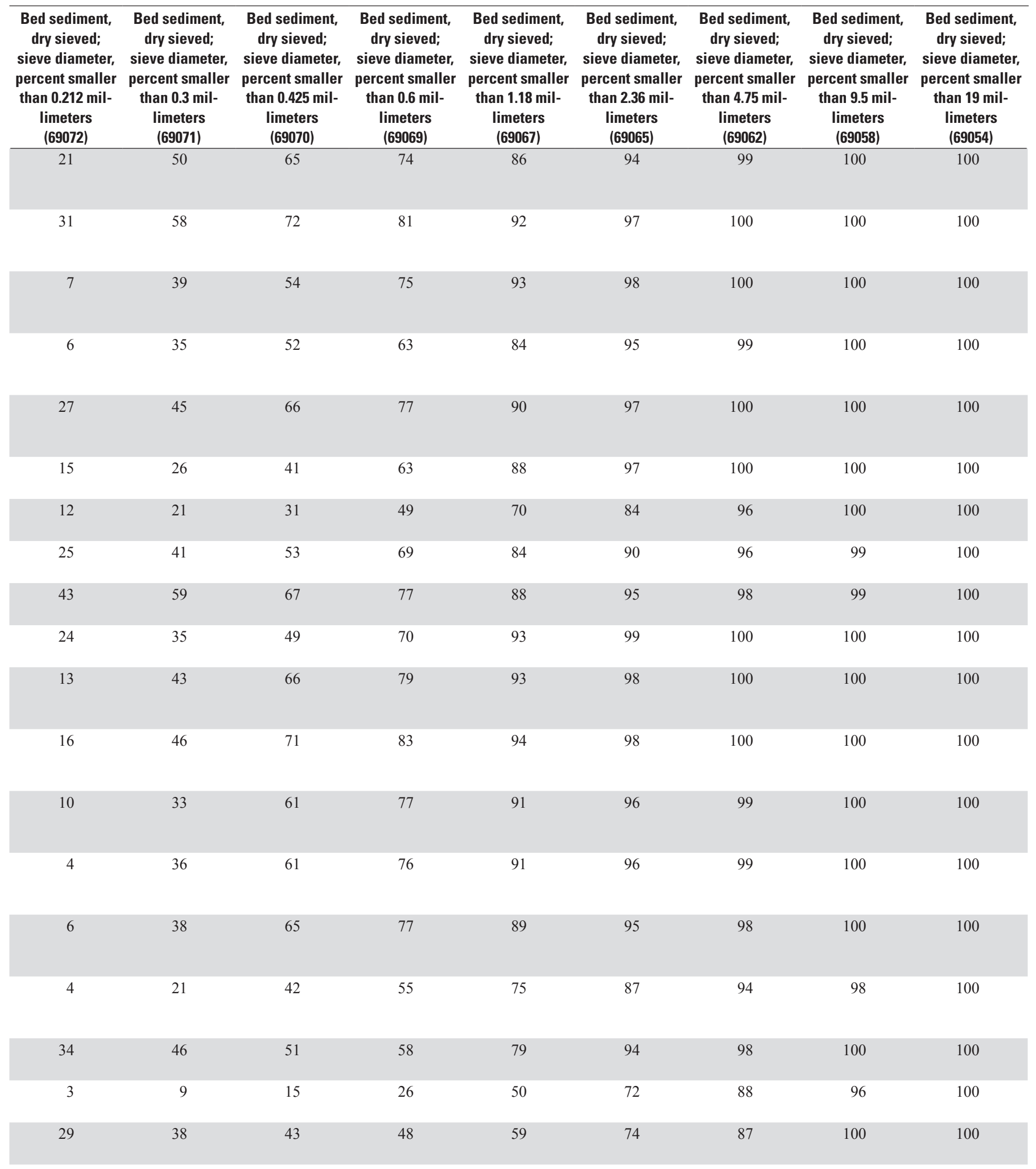


Appendix 2. Streambed sediment Upper Hamburg and Glovers Point Bends, Missouri River, 2008._Continued

[STAID, station identification number; yyyymmdd, date format in 4-digit year, 2-digit month, and 2-digit day; hhmm, 24-hour time format in 2-digit hour and 2-digit minute; USGS National Water Information System parameter numbers given in parentheses; R, river; NE, Nebraska; --, not measured]

\begin{tabular}{|c|c|c|c|c|c|c|c|c|c|}
\hline Transect name & $\begin{array}{l}\text { U.S. Geological } \\
\text { Survey STAID }\end{array}$ & $\begin{array}{l}\text { DATES, } \\
\text { yyyymmdd }\end{array}$ & $\begin{array}{l}\text { TIMES, } \\
\text { hhmm }\end{array}$ & $\begin{array}{l}\text { Discharge, } \\
\text { instantaneous, } \\
\text { cubic feet per } \\
\text { second } \\
\text { (00061) }\end{array}$ & $\begin{array}{c}\text { Stream } \\
\text { width, } \\
\text { feet } \\
(00004)\end{array}$ & $\begin{array}{l}\text { Sampler } \\
\text { type } \\
\text { (84164) }\end{array}$ & $\begin{array}{l}\text { Bed sediment, } \\
\text { dry sieved; } \\
\text { sieve diameter, } \\
\text { percent smaller } \\
\text { than } 0.0625 \text { mil- } \\
\text { limeters } \\
\text { (80164) }\end{array}$ & $\begin{array}{l}\text { Bed sediment, } \\
\text { dry sieved; } \\
\text { sieve diameter, } \\
\text { percent smaller } \\
\text { than } 0.075 \text { mil- } \\
\text { limeters } \\
\text { (69075) }\end{array}$ & $\begin{array}{l}\text { Bed sediment, } \\
\text { dry sieved; } \\
\text { sieve diameter, } \\
\text { percent smaller } \\
\text { than } 0.15 \text { mil- } \\
\text { limeters } \\
(69073)\end{array}$ \\
\hline $\begin{array}{l}\text { Upper Hamburg Chute, } \\
\text { NE Inlet }\end{array}$ & 403701095460001 & 20080911 & 1530 & 2,790 & 268 & US BM-54 & 15 & 18 & 39 \\
\hline $\begin{array}{l}\text { Missouri R at Upper } \\
\text { Hamburg Chute, NE } \\
\text { Upstream }\end{array}$ & 403712095460601 & 20080623 & 1810 & 39,000 & 825 & US BM-54 & 0 & 1 & 4 \\
\hline $\begin{array}{l}\text { Missouri R at Upper } \\
\text { Hamburg Chute, NE } \\
\text { Upstream }\end{array}$ & 403712095460601 & 20080701 & 1630 & 40,300 & 780 & US BM-54 & 10 & 11 & 16 \\
\hline $\begin{array}{l}\text { Missouri R at Upper } \\
\text { Hamburg Chute, NE } \\
\text { Upstream }\end{array}$ & 403712095460601 & 20080911 & 1100 & 30,500 & 675 & US BM-54 & 2 & 2 & 4 \\
\hline $\begin{array}{l}\text { Missouri R at Upper } \\
\text { Hamburg Chute, NE } \\
\text { Upstream }\end{array}$ & 403712095460601 & 20081125 & 1600 & 22,900 & 755 & US BM-54 & 1 & 1 & 2 \\
\hline $\begin{array}{l}\text { Missouri R at } \\
\text { Glovers Chute, NE } \\
\text { Downstream }\end{array}$ & 421410096200401 & 20080605 & 1640 & 27,600 & 690 & US BM-54 & 1 & 1 & 3 \\
\hline $\begin{array}{l}\text { Missouri R at } \\
\text { Glovers Chute, NE } \\
\text { Downstream }\end{array}$ & 421410096200401 & 20080702 & 1310 & 19,800 & 600 & US BM-54 & 0 & 0 & 0 \\
\hline $\begin{array}{l}\text { Glovers Chute, NE } \\
\text { Outlet }\end{array}$ & 421417096200701 & 20080702 & 1410 & 28 & 44 & US BMH-53 & 1 & 1 & 17 \\
\hline $\begin{array}{l}\text { Glovers Chute, NE } \\
\text { Outlet }\end{array}$ & 421417096200701 & 20080903 & 1700 & 248 & 125 & US BMH-53 & 17 & 20 & 37 \\
\hline $\begin{array}{l}\text { Glovers Chute, NE } \\
\text { Outlet }\end{array}$ & 421417096200701 & 20080912 & 1300 & 132 & 115 & US BMH-53 & 9 & 10 & 40 \\
\hline $\begin{array}{l}\text { Missouri R at } \\
\text { Glovers Chute, NE } \\
\text { Midpoint }\end{array}$ & 421455096194201 & 20080605 & 1620 & 27,300 & 630 & US BM-54 & 0 & 0 & 2 \\
\hline $\begin{array}{l}\text { Missouri R at } \\
\text { Glovers Chute, NE } \\
\text { Midpoint }\end{array}$ & 421455096194201 & 20080702 & 1250 & 19,800 & 600 & US BM-54 & 0 & 0 & 1 \\
\hline $\begin{array}{l}\text { Missouri R at } \\
\text { Glovers Chute, NE } \\
\text { Midpoint }\end{array}$ & 421455096194201 & 20080903 & 1300 & 27,900 & 673 & US BM-54 & 9 & 10 & 15 \\
\hline
\end{tabular}




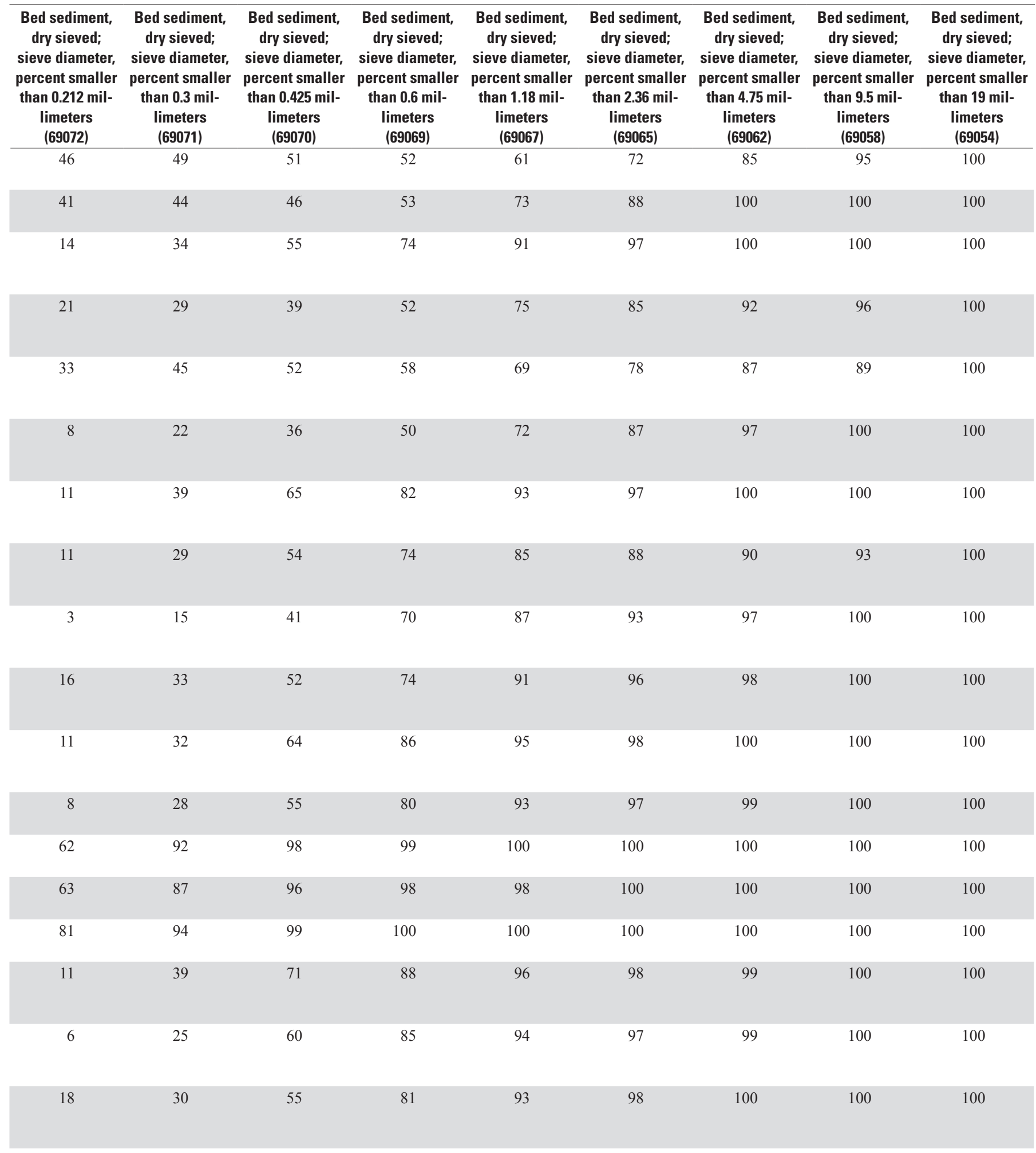


Appendix 2. Streambed sediment Upper Hamburg and Glovers Point Bends, Missouri River, 2008.-Continued

STAID, station identification number; yyyymmdd, date format in 4-digit year, 2-digit month, and 2-digit day; hhmm, 24-hour time format in 2-digit hour and 2-digit minute; USGS National Water Information System parameter numbers given in parentheses; R, river; NE, Nebraska; --, not measured]

\begin{tabular}{|c|c|c|c|c|c|c|c|c|c|}
\hline Transect name & $\begin{array}{l}\text { U.S. Geological } \\
\text { Survey STAID }\end{array}$ & $\begin{array}{c}\text { DATES, } \\
\text { yyyymmdd }\end{array}$ & $\begin{array}{l}\text { TIMES, } \\
\text { hhmm }\end{array}$ & $\begin{array}{l}\text { Discharge, } \\
\text { instantaneous, } \\
\text { cubic feet per } \\
\text { second } \\
\text { (00061) }\end{array}$ & $\begin{array}{c}\text { Stream } \\
\text { width, } \\
\text { feet } \\
\text { (00004) }\end{array}$ & $\begin{array}{l}\text { Sampler } \\
\text { type } \\
(84164)\end{array}$ & $\begin{array}{c}\text { Bed sediment, } \\
\text { dry sieved; } \\
\text { sieve diameter, } \\
\text { percent smaller } \\
\text { than } 0.0625 \text { mil- } \\
\text { limeters } \\
\text { (80164) }\end{array}$ & $\begin{array}{l}\text { Bed sediment, } \\
\text { dry sieved; } \\
\text { sieve diameter, } \\
\text { percent smaller } \\
\text { than } 0.075 \text { mil- } \\
\text { limeters } \\
(69075)\end{array}$ & $\begin{array}{c}\text { Bed sediment, } \\
\text { dry sieved; } \\
\text { sieve diameter, } \\
\text { percent smaller } \\
\text { than } 0.15 \text { mil- } \\
\text { limeters } \\
\text { (69073) }\end{array}$ \\
\hline $\begin{array}{l}\text { Missouri R at } \\
\text { Glovers Chute, NE } \\
\text { Midpoint }\end{array}$ & 421455096194201 & 20080912 & 1100 & 24,500 & 665 & US BM-54 & 0 & 0 & 1 \\
\hline $\begin{array}{l}\text { Glovers Chute, NE } \\
\text { Inlet }\end{array}$ & 421556096202201 & 20080605 & 1530 & 367 & 60 & US BM-54 & 7 & 9 & 31 \\
\hline $\begin{array}{l}\text { Glovers Chute, NE } \\
\text { Inlet }\end{array}$ & 421556096202201 & 20080702 & 1040 & 28 & 56 & US BMH-53 & 6 & 8 & 33 \\
\hline $\begin{array}{l}\text { Glovers Chute, NE } \\
\text { Inlet }\end{array}$ & 421556096202201 & 20080702 & $1047^{\mathrm{a}}$ & 28 & -- & US BMH-53 & 5 & 6 & 29 \\
\hline $\begin{array}{l}\text { Glovers Chute, NE } \\
\text { Inlet }\end{array}$ & 421556096202201 & 20080903 & 1500 & 248 & 50 & US BM-54 & 5 & 7 & 22 \\
\hline $\begin{array}{l}\text { Glovers Chute, NE } \\
\text { Inlet }\end{array}$ & 421556096202201 & 20080912 & 900 & 132 & 58 & US BM-54 & 28 & 32 & 65 \\
\hline $\begin{array}{l}\text { Missouri R at } \\
\text { Glovers Chute, NE } \\
\text { Upstream }\end{array}$ & 421606096202701 & 20080605 & 1540 & 27,600 & 750 & US BM-54 & 0 & 0 & 1 \\
\hline $\begin{array}{l}\text { Missouri R at } \\
\text { Glovers Chute, NE } \\
\text { Upstream }\end{array}$ & 421606096202701 & 20080702 & 1150 & 19,800 & 600 & US BM-54 & 13 & 15 & 32 \\
\hline $\begin{array}{l}\text { Missouri R at } \\
\text { Glovers Chute, NE } \\
\text { Upstream }\end{array}$ & 421606096202701 & 20080903 & 1400 & 28,100 & 704 & US BM-54 & 6 & 7 & 10 \\
\hline $\begin{array}{l}\text { Missouri R at } \\
\text { Glovers Chute, NE } \\
\text { Upstream }\end{array}$ & 421606096202701 & 20080912 & 1000 & 24,600 & 639 & US BM-54 & 1 & 2 & 9 \\
\hline
\end{tabular}

${ }^{a}$ Replicate sample collected to assess field variability. 


\begin{tabular}{|c|c|c|c|c|c|c|c|c|}
\hline $\begin{array}{l}\text { Bed sediment, } \\
\text { dry sieved; } \\
\text { sieve diameter, } \\
\text { percent smaller } \\
\text { than } 0.212 \text { mil- } \\
\text { limeters } \\
\text { (69072) } \\
\end{array}$ & $\begin{array}{l}\text { Bed sediment, } \\
\text { dry sieved; } \\
\text { sieve diameter, } \\
\text { percent smaller } \\
\text { than } 0.3 \text { mil- } \\
\text { limeters } \\
\text { (69071) }\end{array}$ & $\begin{array}{l}\text { Bed sediment, } \\
\text { dry sieved; } \\
\text { sieve diameter, } \\
\text { percent smaller } \\
\text { than } 0.425 \text { mil- } \\
\text { limeters } \\
(69070)\end{array}$ & $\begin{array}{l}\text { Bed sediment, } \\
\text { dry sieved; } \\
\text { sieve diameter, } \\
\text { percent smaller } \\
\text { than } 0.6 \text { mil- } \\
\text { limeters } \\
\text { (69069) }\end{array}$ & $\begin{array}{l}\text { Bed sediment, } \\
\text { dry sieved; } \\
\text { sieve diameter, } \\
\text { percent smaller } \\
\text { than } 1.18 \text { mil- } \\
\text { limeters } \\
\text { (69067) }\end{array}$ & $\begin{array}{l}\text { Bed sediment, } \\
\text { dry sieved; } \\
\text { sieve diameter, } \\
\text { percent smaller } \\
\text { than } 2.36 \text { mil- } \\
\text { limeters } \\
\text { (69065) }\end{array}$ & $\begin{array}{l}\text { Bed sediment, } \\
\text { dry sieved; } \\
\text { sieve diameter, } \\
\text { percent smaller } \\
\text { than } 4.75 \text { mil- } \\
\text { limeters } \\
(69062)\end{array}$ & $\begin{array}{l}\text { Bed sediment, } \\
\text { dry sieved; } \\
\text { sieve diameter, } \\
\text { percent smaller } \\
\text { than } 9.5 \text { mil- } \\
\text { limeters } \\
\text { (69058) }\end{array}$ & $\begin{array}{c}\text { Bed sediment, } \\
\text { dry sieved; } \\
\text { sieve diameter, } \\
\text { percent smaller } \\
\text { than } 19 \text { mil- } \\
\text { limeters } \\
\text { (69054) }\end{array}$ \\
\hline 6 & 31 & 73 & 95 & 99 & 100 & 100 & 100 & 100 \\
\hline 74 & 93 & 96 & 96 & 97 & 99 & 100 & 100 & 100 \\
\hline 75 & 91 & 95 & 96 & 97 & 99 & 100 & 100 & 100 \\
\hline 71 & 89 & 93 & 95 & 97 & 98 & 100 & 100 & 100 \\
\hline 3 & 13 & 35 & 72 & 91 & 97 & 99 & 100 & 100 \\
\hline 74 & 91 & 95 & 97 & 98 & 99 & 100 & 100 & 100 \\
\hline 14 & 32 & 65 & 85 & 93 & 97 & 99 & 100 & 100 \\
\hline 17 & 36 & 61 & 86 & 96 & 99 & 100 & 100 & 100 \\
\hline
\end{tabular}


Publishing support provided by:

Rolla Publishing Service Center

For more information concerning this publication, contact:

Director, USGS Nebraska Water Science Center

5231 South 19 Street

Lincoln, NE 68512

(402) 328-4100

Or visit the Nebraska Water Science Center Web site at: http://ne.water.usgs.gov 

产 